\title{
Kasztelanowa lubelska Krystyna z Uhruska Sienieńska i jej testament z 2 czerwca 1639 r. Nieznana karta $z$ dziejów i genealogii rodziny Uhrowieckich herbu Suchekomnaty w XVI i XVII wieku
}

Abstract

Krystyna from Uhrusk Sienieńska, wife of the castellan of Lublin and her last will of June 2, 1639. Unknown chart from the history and genealogy of Uhrowiecki family, Suchekomnaty coat of arms in $16^{\text {th }}$ and $17^{\text {th }}$ century

\begin{abstract}
K rystyna Uhrowiecka, Suchekomnaty coat of arms was a representative of a well-known family of Ruthenian origin who settled in the Chelm region. On the basis of researched sources, it was possible not only to present an outline of her biography, but also to develop the genealogy of the Uhrowiecki family in the $16^{\text {th }}$ and first half of the $17^{\text {th }}$ century, unknown in principle to heraldist. The author managed to identify the parents, grandfathers and great-grandfathers of the heroine of this study. The article presents short biographies of ancestors and relatives from the male line of Krystyna Uhrowiecka. The second part of the study was devoted to her. The daughter of Mikołaj, starost of Chełm, Krystyna got married twice. The first time she was a wife of the chamberlain of Mielnik, Kasper Dembiński, and the second time of Zbigniew Sienieński, castellan of Lublin. With her first husband, she had a daughter, Franciszka Katarzyna. To the second one she gave birth to six children - sons Mikołaj, Stanisław, Zbigniew and Tomasz, as well daughters Anna and Eufrozyna. The wife of the castellan of Lublin turned out to be a very resourceful and foresighted person. She managed to accumulate quite significant fortune, which she donated to the children. On June 2, 1639, she made a very interesting will, a critical edition of which was attached to the text presented here. She probably died soon after dictating her last will, i.e. still in 1639.
\end{abstract}


Keywords: Krystyna Uhrowiecka, Uhrowiecki family, Sienieński family, Kasper Dembiński, Zbigniew Sienieński, Polish nobility, history of the Polish-Lithuanian Commonwealth in the $16^{\text {th }}$ and $17^{\text {th }}$ centuries, genealogy, last will, source edition

\section{STRESZCZENIE}

Kros rec rystyna Uhrowiecka h. Suchekomnaty była przedstawicielka znanej rodziny pochodzenia ruskiego osiadłej w ziemi chełmskiej. Na podstawie przebadanych źródeł można było pokusić się nie tylko o przedstawienie zarysu jej biografii, lecz także o opracowanie w zasadzie nieznanej heraldykom genealogii rodziny Uhrowieckich w XVI i pierwszej połowie XVII w. Autorowi udało się zidentyfikować rodziców, dziadów i pradziadów bohaterki studium. W artykule przedstawiono krótkie biogramy przodków i krewnych z linii męskiej Krystyny Uhrowieckiej. Jej samej poświęcono druga część opracowania. Córka starosty chełmskiego Mikołaja, Krystyna dwukrotnie wychodziła za mąż. Po raz pierwszy za podkomorzego mielnickiego Kaspra Dembińskiego, po raz drugi zaś za Zbigniewa Sienieńskiego, kasztelana lubelskiego. $Z$ pierwszym mężem miała córkę Franciszkę Katarzynę. Drugiemu urodziła sześcioro dzieci: synów Mikołaja, Stanisława, Zbigniewa i Tomasza oraz córki Annę i Eufrozynę. Kasztelanowa lubelska okazała się osoba bardzo zaradna i zapobiegliwą. Udało się jej zgromadzić dość znaczny majatek, który przekazała dzieciom. W dniu 2 czerwca 1639 r. sporządziła bardzo ciekawy testament, którego krytyczna edycja została załączona do prezentowanego tu tekstu. Zmarła zapewne wkrótce po podyktowaniu swojej ostatniej woli, a więc jeszcze w 1639 r.

Słowa kluczowe: Krystyna Uhrowiecka, rodzina Uhrowieckich, rodzina Sienieńskich, Kasper Dembiński, Zbigniew Sienieński, szlachta polska, dzieje Rzeczypospolitej w XVI i XVII wieku, genealogia, testament, edycja źródłowa

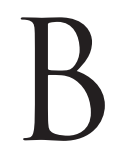
ohaterka niniejszego studium pochodziła ze starej, ruskiej rodziny bojarskiej osiadłej w ziemi chełmskiej, gdzie Uhrowieccy h. Suchekomnaty od początku XV stulecia należeli do miejscowej elity. Zanim przejdziemy do przedstawienia dziejów jej ciekawego żywota, wypada poświęcić kilka słów bezpośrednim przodkom Krystyny Uhrowieckiej. Protoplasta rodu był Olechno Dymitrowicz, zwany też Olechną Białym, który w drugim dziesięcioleciu XV w. otrzymał od Władysława Jagiełly nadanie Uhruska $z$ dworzyszczem Bytyń, Łukówka, Sobiboru, Pulma z jeziorem tej samej nazwy oraz Pniówna i Piszczy w powiecie chełmskim. W 1416 r. Olechno z Uhruska objął być może na krótko urząd starosty chełmskiego, $\mathrm{z}$ którego jednak w tym samym jeszcze roku ustapił. Po raz ostatni został odnotowany w 1448 r. Zmarł prawdopodobnie niedługo potem. Pozostawił po sobie dwóch synów Iwaszkę i Andruszkę. Iwaszko Olechnowicz zmarł bezpotomnie, 
najpewniej wkrótce po śmierci ojca. Andruszko natomiast żył przynajmniej do początku lat siedemdziesiątych XV stulecia. Nie żył już na pewno w 1472 r. Andruszko Olechnowicz był żonaty $z$ Hanka, siostra Zofii, żony zmarłego przed 1475 r. Iwana ks. Sanguszki, dzierżawcy drohickiego. $Z$ tego małżeństwa Andruszko Uhrowiecki pozostawił synów Michnę (Mikołaja), Olechnę i Jaczka (Jacka). Dwaj starsi synowie Andruszki zmarli bezpotomnie. Michno przed 1487, a Olechno przed 1502 r. Najmłodszy z braci - Jaczko Uhrowiecki w 1501 r. otrzymał urząd miecznika chełmskiego. W 1504 r. awansował na łowczego chełmskiego, który to urząd sprawował do śmierci. Zmarł w 1511 lub 1512 r. Jacek Uhrowiecki ożenił się $z$ Chwiedką, córką Senka Denikiewicza, która po jego śmierci wyszła ponownie za mąż - za Dymitra $z$ Podhorodna. $Z$ małżeństwa $z$ Chwiedką Senkówną łowczy chełmski pozostawił synów Stanisława, Mikołaja, Lwa i Jana oraz córkę Annę. Ta ostatnia w 1514 r. wyszła za mąż za Feliksa (Szczęsnego) Zamoyskiego (zm. 1535), w przyszłości podkomorzego chełmskiego, wnosząc mu w posagu bardzo wysoka na owe czasy sumę 1100 florenów. Warto w tym miejscu zwrócić uwage na to, że w chwili śmierci Jaczka (Jacka) Uhrowieckiego, który był pradziadem kasztelanowej lubelskiej, jego trzej młodsi synowie byli jeszcze niepełnoletni i zostali oddani pod opiekę księdza Mikołaja Zamoyskiego, rodzonego brata wspomnianego Feliksa ${ }^{1}$.

Spośród synów łowczego chełmskiego dwaj - Mikołaj i Lew zmarli młodo i bezpotomnie. O dwóch pozostałych wiemy natomiast stosunkowo dużo. Nie wdając się w szczegóły, powiedzmy tylko, że Stanisław Uhrowiecki żenił się dwukrotnie. Jego pierwszą żona, poślubiona przed 1510 r., była Anna z Sosnowicy. Małżeństwo to było bezdzietne. Po raz drugi najstarszy syn Jacka ożenił się z Katarzyna Sienicką h. Bończa, córką Stanisława (zm. 1543) podkomorzego bełskiego i Barbary Róża Boryszewskiej h. Poraj, siostrą sławnego przywódcy ruchu egzekucyjnego Mikołaja Sienickiego. Pod koniec życia Stanisław Uhrowiecki otrzymał sprawowany wcześniej przez ojca urząd łowczego chełmskiego. Zmarł przed 22 lutego 1544 r., kiedy to król Zygmunt I nadał wakujące

${ }^{1}$ Szczegółowe omówienie dziejów życia i dokonań wspomnianych tu przedstawicieli rodziny Uhrowieckich por. W. Czarn e cki, Uhrowieccy herbu Suchekomnaty $w$ ziemi chełmskiej do połowy XVI wieku, "Wschodni Rocznik Humanistyczny” 2009, t. VI, s. 10-22. Por. też Urzędnicy województwa bełskiego i ziemi chełmskiej XIV-XVIII wieku. Spisy [dalej: Urzędnicy bełscy], oprac. H. Gmiterek i R. Szczygieł, red. A. Gąsiorowski, Kórnik 1992, nr 1129, 1164, 1400. 
po nim łowczostwo chełmskie Stanisławowi Zamoyskiemu². Katarzyna z Sienickich dość znacznie przeżyła męża. Żyła jeszcze przynajmniej do roku 1568. Nie żyła już prawdopodobnie w styczniu 1571 r. Z małżeństwa $z$ Katarzyna Stanisław Uhrowiecki pozostawił syna Mikołaja oraz cztery córki: Barbarę, Annę, Zofię i Potencjannę $e^{3}$ Jedyny syn łowczego chełmskiego Stanisława - Mikołaj, urodzony w 1537 r., otrzymał bardzo staranne wykształcenie. Dnia 15 stycznia 1552 r. wpisał się do albumu studentów uniwersytetu w Wittenberdze. W latach 1553-1555 studiował w Bazylei, a następnie przeniósł się do Paryża, gdzie podjął studia w Collège de France. Podobno znał łacinę, grekę i język hebrajski. Niestety nie było mu dane rozwinąc wszystkich swoich talentów. Mikołaj Uhrowiecki zmarł bowiem w stolicy Francji w 1557 r. w wieku zaledwie 20 lat. W paryskim kościele Saint-Étienne-du-Mont zachowała się upamiętniająca go tablica epitafijna ufundowana przez jego przyjaciół, Bazylego Drzewińskiego i Aleksego Drohiczyńskiego (Drohiczańskiego) ${ }^{4}$.

${ }^{2}$ Por. W. Czarnecki, op. cit., s. 22-23; Urzędnicy bełscy, nr 1135; H. G miterek, Sienicki Stanisław, [w:] Polski słownik biograficzny [dalej: PSB], t. XXXVII, Warszawa-Kraków 1996-1997, s. 162-163 (tu jednak brak imienia córki wydanej za Uhrowieckiego i bliższych informacji o jej mężu).

${ }^{3}$ Por. W. Czarnecki, op. cit., s. 23 (tu jednak błędne stwierdzenie, że oprócz Mikołaja, łowczy chełmski Stanisław miał również synów Marcina i Wacława); Archiwum Państwowe w Lublinie [dalej: APL], Chełmskie grodzkie, Relacje, nr 1, s. 86-88 (tu Katarzyna $z$ Sienicy Różanej Uhrowiecka w sporze $z$ bratankiem męża, Marcinem Uhrowieckim o grunty i młyn we wsi Pulmo - rok 1565); Chełmskie grodzkie, Zapisy [dalej: ChGZ], nr 5, s. 389 (tu Mikołaj Sienicki, podkomorzy chełmski, otrzymuje intromisję do dóbr Uhrusk, Uhrowska Wola, Pulmo i Wola Pulmowska należących do jego siostrzenic, Barbary Hańskiej, Anny Latyczyńskiej, Zofii Gorajskiej i Potencjanny Krzywczyckiej - rok 1571). Warto zwrócić uwagę na fakt, że genealogom znani sa jedynie mężowie dwóch młodszych łowczanek chełmskich. Zgodnie $z$ ustaleniami Adama Bonieckie go mężem Zofii był Jerzy Gorajski, a Potencjanny - Wawrzyniec Krzywczycki. Por. idem, Herbarz polski, t. VI, Warszawa 1903, s. 233; t. XIII, Warszawa 1909, s. 34. Odnotujmy także, że Katarzyna $z$ Sienickich Uhrowiecka w latach 1556-1558 spławiała do Gdańska znaczne ilości zboża $z$ trzymanych w dożywociu majątków po mężu (w sumie 46 łasztów wysłanych samodzielnie oraz 30 łasztów spławionych wspólnie $z$ bratem, podkomorzym chełmskim Mikołajem Sienickim). Z cała pewnościa to właśnie ona (w rejestrze pominięto imię wspomnianej tam Uhrowieckiej) spławiła też 33 laszty zboża do portu nad Motława w 1568 r. por. Regestra thelonei aquatici Wladislaviensis saeculi XVI [dalej: RTAW], wyd. S. Kutrzeba, F. Duda, Kraków 1915, s. 84, 119, 132, 216, 233.

${ }^{4}$ Por. Album Academiae Vitebergensis ab A. Ch. MDII usque ad A. MDLX, ed. C.E. Foerstmann, vol. I, Lipsiae 1841, s. 273; Polacy w Bazylei. $Z$ metryk Uniwersytetu Bazylejskiego, wyd. J. Kallenbach, Kraków 1888, s. 5; W. Bon dy ra, 
Dziadek naszej bohaterki, Jan Uhrowiecki był najmłodszym synem łowczego chełmskiego Jacka i jego żony Chwiedki. W źródłach zaczął się pojawiać od 1519 r. W 1522 r. był wraz z bratem Stanisławem domownikiem swego dawnego opiekuna, księdza Mikołaja Zamoyskiego, kanonika krakowskiego, proboszcza chełmskiego, tarnowskiego i wojnickiego. Towarzyszac swojemu patronowi, obaj Uhrowieccy przez jakiś czas przebywali na dworze królewskim. Na początku lat trzydziestych XVI w. Jan Uhrowiecki procesował się $z$ władyka chełmskim Filaretem. W 1528 r. lub też nieco wcześniej otrzymał urząd podstolego chełmskiego. Zgromadził w swoim ręku dość znaczny majątek, na który składały się wsie Uhrusk (część), Pniówno, Łukówek, Bukowa, Sobibór i Piszcza. W 1543 r. król Zygmunt I zatwierdził darowiznę Hieronima Smoka, pana na Czułczycach, który oddalił od spadku krewnych i przekazał swoje dobra Zygmuntowi Augustowi, Stanisławowi Tęczyńskiemu i Janowi Uhrowieckiemu. Ten ostatni otrzymał wówczas w dziedziczne władanie wieś Sielec. W latach 1555-1557 podstoli chełmski spławiał ze swoich dóbr znaczne ilości zboża do Gdańska. Jak można przypuszczać, zmarł przed rokiem $1561^{5}$. Jan Uhrowiecki ożenił się z Anną Zamoyską h. Jelita, córką podkomorzego chełmskiego Feliksa (Szczęsnego), która wniosła mu 200 florenów posagu. Rzecz jasna żona podstolego chełmskiego nie mogła być córką jego siostry Anny, od 1514 r. będącej żoną tego samego Feliksa Zamoyskiego. Nie ulega zatem najmniejszej nawet wątpliwości, że była ona jedna $z$ dwóch córek późniejszego podkomorzego chełmskiego $z$ jego pierwszego małżeństwa, z poślubiona w 1501 r. Dorotą

\footnotetext{
Starostowie chetmscy $w$ XVI wieku. Charakterystyka grupy, „Annales Universitatis Mariae Curie-Skłodowska, sectio F - Historia” 1991/1992, vol. XLVI/XLVII, s. 151 (tu jednak pomylono zmarłego w 1557 r. łowczyca chełmskiego $z$ jego bratem stryjecznym, także Mikołajem, późniejszym starostą chełmskim i temu ostatniemu przypisano odbyte przez niego studia); W. Dwo rzaczek, Hetman Jan Tarnowski. $Z$ dziejów możnowładztwa małopolskiego, Warszawa 1985, s. 188, 278; A. Hanula, Kościót St Étienne du Mont w Paryżu i dwaj tajemniczy polscy studenci, https:/ / polskifr.fr/polska-we-francji/kosciol-st-etienne-du-mont-wparyzu-i-dwaj-tajemniczy-polscy-studenci/ (dostęp: 16 VIII 2021).

${ }_{5}^{5}$ Por. W. Czarnecki, op. cit., s. 22-24; B. Paprocki, Herby rycerstwa polskiego, wyd. K.J. Turowski, Kraków 1858, s. 260; K. Nies iecki, Herbarz polski, wyd. J.N. Bobrowicz, t. IX, Lipsk 1842, s. 195; Urzędnicy bełscy, nr 1328; RTAW, s. 45, 85, 119 (w sumie Jan Uhrowiecki w ciagu trzech lat wysłał do Gdańska 132 łaszty zboża). W 1561 r. na komorze celnej we Włocławku jako organizatora spławu odnotowano po raz pierwszy syna podstolego chełmskiego, Marcina. Może to świadczyć o tym, że Jan Uhrowiecki w tym czasie już nie żył.
} 
Smokówną h. Ślepowron. Włodzimierz Czarnecki twierdzi, że Jan Uhrowiecki ożenił się z Anną Zamoyską w 1519 r. Wydaje się to jednak mało prawdopodobne i w rzeczywistości termin ich ślubu należałoby przesunąc przynajmniej na rok $1528^{6}$. Z małżeństwa tego pochodziło trzech synów: Marcin, Wacław i Mikołaj.

Niebagatelne znaczenie dla przyszłości młodych Uhrowieckich miało bliskie pokrewieństwo łączące ich $z$ rodziną Zamoyskich h. Jelita. Rodzona siostra ich ojca - Anna Uhrowiecka była matka kasztelana chełmskiego Stanisława (zm. 1572) i Floriana (zm. 1587), który zakończył swoją karierę na urzędzie kasztelana bełskiego. Przyrodnia siostra obu Zamoyskich była natomiast matka braci Uhrowieckich. Rzecz jasna koligacja ta nabrała znaczenia dopiero wtedy, gdy syn Stanisława - Jan Zamoyski zaczał robić błyskawiczna karierę u boku króla Stefana Batorego, sięgajac $\mathrm{w}$ ostatecznym rozrachunku po urzędy kanclerza i hetmana wielkiego koronnego. Wypada zatem zwrócić uwagę na fakt, że pierwszy ordynat na Zamościu był spokrewniony z Uhrowieckimi nie tylko przez swoją babkę, lecz także przez siostrę swojego ojca. Synowie podstolego chełmskiego byli więc zarówno jego wujami, jak i braćmi ciotecznymi. Bliskie pokrewieństwo łączące Jana Zamoyskiego $z$ Uhrowieckimi nie stanowiło tajemnicy dla współczesnych. Kasztelan sochaczewski Stanisław Gostomski w liście

${ }^{6}$ W. Czarnecki, op. cit., s. 23; K. Sochaniewicz, Ze studjów nad rozsiedleniem szlachty $w$ ziemi chełmskiej. Smokowie Ślepowrony $w$ XV i XVI $w$. na Chetmszczyźnie, przybysze z Mazowsza, „Rocznik Towarzystwa Heraldycznego we Lwowie” 1924-1925, t. VII, s. 192-194 (tu m.in. informacja, że Dorota Zamoyska była córka Stanisława Smoka). Dodajmy, że z przytoczonego przez W. Czarneckiego dokumentu wynika, że w chwili ślubu z Anną Zamoyska Jan Uhrowiecki był już podstolim chełmskim. $Z$ pewnością nie mógł on otrzymać tego urzędu w roku 1519, zważywszy na to, że w 1512 r. był jeszcze niepełnoletni, a miał przecież jeszcze dwóch starszych, również niepełnoletnich wówczas braci. Był zatem zbyt młody, aby w 1519 r. piastować jakikolwiek urząd ziemski. Po raz pierwszy odnotowano go w źródłach jako podstolego chełmskiego w 1528 r. (Urzędnicy bełscy, $\mathrm{nr}$ 1328) i jest to najwcześniejsza możliwa data zawarcia przez niego zwiąku małżeńskiego. Warto również w tym miejscu zwrócić uwage na to, że Hieronim Smok z Czułczyc był bratankiem Doroty ze Smoków Zamoyskiej. Najpewniej zatem z tego właśnie powodu darował on w 1543 r. wieś Sielec Janowi Uhrowieckiemu, który był mężem jego siostry ciotecznej. Odnotujmy także, że do czasu wystapienia W. Czarneckiego znana była tylko jedna córka Feliksa Zamoyskiego i Doroty Smokówny - Barbara, która zmarła prawdopodobnie młodo jako panna. Por. K. Niesiecki, op. cit., t. X, Lipsk 1845, s. 59; S. Duńczews ki, Herbarz wielu domow Korony Polskiey y W. X. Litewskiego, t. I, Kraków 1757, s. 191 (tu błędna informacja, że Dorota Smokówna była matką wszystkich dzieci Feliksa Zamoyskiego). 
pisanym do kanclerza wielkiego koronnego w maju 1578 r. wprost nazwał Wacława Uhrowieckiego „bratem” swojego korespondenta ${ }^{7}$.

Spośród synów podstolego chełmskiego Jana Uhrowieckiego i Anny Zamoyskiej niewatpliwie najstarszy był Marcin. Można o nim powiedzieć to, że w przeciwieństwie do młodszych braci nie związał swojej kariery $z$ potężnym krewniakiem $z$ Zamościa. Nie był też zbyt aktywny na scenie politycznej. Podejmował za to szereg inicjatyw natury gospodarczej. Już w 1561 r. spławił ze swoich dóbr do Gdańska 90 łasztów wańczosu i klepki. Od 1568 do 1575 r. regularnie odnotowywano też na komorze celnej we Włocławku wysyłane przez niego do portu nad Motława transporty zboża (w sumie 255 łasztów). W 1576 r. spławił zaś do Gdańska 16 łasztów potażu. Przed 1569 r. Marcin Uhrowiecki ożenił się z Anną Reyówną h. Oksza, córką słynnego poety Mikołaja Reya $z$ Nagłowic i Zofii Kościeniówny (Kosnówny) h. Jastrzębiec. Był już w tym czasie najpewniej łowczym chełmskim, z którym to urzędem został odnotowany w źródłach w 1570 r. Ze spadku po ojcu objął Łukówek (Łukowa) i Bukową. Na początku lat siedemdziesiątych XVI w. był także właścicielem Starej Mszany i Nowej Woli. Od szwagrów Krzysztofa i Andrzeja Reyów przejął w styczniu 1571 r. Plisków i Olszankę. U schyłku życia w jego posiadaniu znalazły się również stare rodzinne posiadłości - Sobibór i Piszcza. Wszystkie wspomniane tu wsie leżały w ziemi chełmskiej. W roku 1586 Marcin Uhrowiecki został senatorem, obejmując po Florianie Zamoyskim drażkową kasztelanię chełmską. W lutym 1588 r. otrzymał w dożywocie dzierżawę ceł włocławskich (przyznaną wcześniej jego

7 Por. Urzędnicy bełscy, nr 61 i 1103; Stanisław Gostomski do Jana Zamoyskiego, Chełm 7 V 1578, Archiwum Jana Zamoyskiego kanclerza $i$ hetmana wielkiego koronnego [dalej: AJZ], t. I (1553-1579), wyd. W. Sobieski, Warszawa 1904, s. 217-218. Zwróćmy w tym miejscu uwage na to, że już wydawca tego tomu korespondencji Jana Zamoyskiego miał problem $z$ określeniem „brat” użytym w liście Gostomskiego. Podał więc bałamutną informację, że zwiąki rodzinne Uhrowieckiego z Zamoyskimi wynikały $z$ tego, że stryj kanclerza Feliks (w rzeczywistości stryj Jana miał na imię Florian) ożeniony był z Katarzyną Uhrowiecką (faktycznie jego żoną była Katarzyna z Orska Dunikowska). Por. ibidem, s. 218. Oznacza to, że W. Sobieski wiedział o małżeństwie dziadka kanclerza z Anną Uhrowiecka, ale pomylił zarówno pokolenia, jak i imiona przywołanych przez siebie osób. Jeszcze bardziej zagmatwała tę kwestię E. Dubas-Urwanowicz, która korzystając $z$ tego samego listu, wbrew temu, co zostało tam wyraźnie napisane, stwierdziła, że określenie „brat” odnosi się nie do Uhrowieckiego, ale do stryja kanclerza, po czym powtórzyła bałamutny przekaz W. Sobieskiego. Por. e a d e m, Mężowie stanu, awanturnicy czy zdrajcy. Dzieje rodu Zborowskich w XVI wieku, Warszawa 2018, s. 496. 
właśnie zmarłemu bratu Wacławowi), z których miał wnosić do skarbu 2300 złotych rocznie. Użytkował również wsie królewskie Chotcza, Petryłów i Wola Petryłowska w ziemi chełmskiej. W lutym 1588 r. dostał od Zygmunta III konsens na ich ustapienie bratankowi żony, Stanisławowi Reyowi z Nagłowic. Transakcja ta nie doszła jednak do skutku. W 1593 r. kasztelan chełmski otrzymał bowiem kolejny konsens, tym razem na ustapienie tej dzierżawy swojemu bratankowi, Janowi Uhrowieckiemu. Nie wiemy co prawda, kiedy Marcin ostatecznie ustapił z Chotcza, ale mamy potwierdzenie źródłowe, że po jego śmierci wszystkie wsie tej dzierżawy znajdowały się w rękach wspomnianego bratanka. Uhrowiecki bez wątpienia był innowiercą. W 1583 r. założył zbór ariański w swojej dziedzicznej wsi Łukowej (Łukówku). Być może później przeszedł jednak na kalwinizm. W 1599 r. został wybrany przez uczestników protestancko-prawosławnego zjazdu wileńskiego jednym $z$ prowizorów ewangelickich. Marcin Uhrowiecki zmarł w końcu 1600 r. (po 4 września). Z małżeństwa $z$ Anną Reyówna nie pozostawił potomstwa. Wszystkie dobra po kasztelanie chełmskim odziedziczyli więc jego brat Mikołaj oraz synowie drugiego brata, Wacława ${ }^{8}$.

Wacław Uhrowiecki był drugim synem Jana, podstolego chełmskiego i Anny Zamoyskiej. Podobnie jak jego starszy brat Marcin, urodził się najpewniej w latach trzydziestych XVI stulecia. $Z$ dziedzictwa po ojcu objął Sielec (we współczesnych źródłach niemal zawsze używano nazwy Sielce). Jako właściciel tej wsi został odnotowany w 1566 r., gdy zabezpieczył na jej połowie pożyczkę w wysokości 1000 florenów zaciągniętą u łowczego bełskiego Stanisława

8 Por. RTAW, s. 237, 271, 284, 298, 315, 336, 371, 404, 437; W. Czarn e cki, op. cit., s. 23; M.J. Kaw ałko, Rejowiec. Jego okolice $i$ właściciele w latach 15311869, Lublin 2011, s. 97, 100-101 (tu jednak błędnie utożsamiono interesujacego nas Marcina Uhrowieckiego $z$ noszacym to samo imię synem jego brata Mikołaja); Urzędnicy bełscy, nr 1106, 1137; APL, ChGZ, nr 5, s. 150-152 (tu Marcin Uhrowiecki jako właściciel Łukowej, Bukowej, Starej Mszany i Nowej Woli); Archiwum Główne Akt Dawnych w Warszawie [dalej: AGAD], Metryka Koronna [dalej: MK] 134, k. 126-126v (nadanie w dożywocie ceł włocławskich), 167v-168v (konsens na ustapienie dóbr Stanisławowi Reyowi); MK 133, k. 581-581v (konsens na ustapienie $z$ Chotczy na rzecz Jana Uhrowieckiego); Biblioteka Kórnicka PAN, sygn. BK $01467 / 1$, „Kolekcja akt dot. procesów granicznych i stosunków własnościowych miasta Szczekocin i okolic z lat 1470-1618", vol. I, nr 33, k. 88-89 (tu informacja, że synowie Wacława Uhrowieckiego Jan i Andrzej odziedziczyli po kasztelanie chełmskim Marcinie Łukową, Sobibór i Piszczę, jak również przejęli po nim wsie królewskie Chotczę, Petryłów i Wolę Petryłowska); H. M e r czyng, Zbory i senatorowie protestanccy $w$ dawnej Polsce, Warszawa 1904, s. 137. 
Miłoszewskiego. W przeciwieństwie do Marcina, Wacław nie angażował się zbytnio w przedsięwzięcia o charakterze gospodarczym. Na komorze celnej we Włocławku odnotowano tylko jeden transport zboża (48 łasztów) spławiony w 1568 r. z jego dóbr do Gdańska. Średni syn podstolego chełmskiego bardzo aktywnie uczestniczył za to w życiu politycznym. Jak można przypuszczać, początkowo korzystał $z$ protekcji swojego powinowatego (brata stryjenki Katarzyny) Mikołaja Sienickiego. Wraz z nim został wybrany posłem ziemi chełmskiej na sejm w 1567 r. Ze swojej rodzinnej ziemi posłował również na sejmy obradujące w latach 1572, 1573 (konwokacja), 1578, 1582, 1585 oraz na sejm koronacyjny Zygmunta III, który obradował na przełomie 1587 i 1588 r. W latach siedemdziesiątych XVI w. związał się ze swoim potężnym krewniakiem Janem Zamoyskim. Początkowo był jego domownikiem i klientem, $z$ czasem jednak stał się powiernikiem i zaufanym doradca kanclerza. W $1581 \mathrm{r}$. Wacław Uhrowiecki otrzymał (wakujacy po śmierci Mikołaja Sienickiego) urzad podkomorzego chełmskiego. W 1584 r. znalazł się w grupie kilkunastu senatorów i współpracowników politycznych Jana Zamoyskiego ze stanu szlacheckiego, których kanclerz poinformowal o aresztowaniu Samuela Zborowskiego i zamiarze jego stracenia. W 1585 r. Uhrowiecki reprezentował interesy Jana Zamoyskiego na przedsejmowym sejmiku chełmskim, wpływając na pomyślna dla króla i kanclerza treść uchwalonej tam instrukcji. W 1587 r. Zamoyski zamierzał wysłać go do Gdańska na rozmowy z jego władzami w sprawie zbliżającej się elekcji nowego władcy. Ostatecznie jednak podkomorzy chełmski do Gdańska nie dotarł. Wacław Uhrowiecki uczestniczył jeszcze w sejmie obradującym na przełomie 1587 i 1588 r. Dnia 9 stycznia 1588 r. otrzymał od Zygmunta III nadanie cła włocławskiego. Ze względu na jego zasługi obniżono mu kwotę dzierżawy z 3000 do 2300 złotych rocznie. Tego samego dnia potwierdzono mu nadana jeszcze przez Stefana Batorego dzierżawę ceł ruskich, które miał trzymać wspólnie $z$ podczaszym chełmskim Pawłem Orzechowskim przez osiem lat, poczynając od 20 lipca 1589 r. I w tym przypadku kwotę dzierżawy obniżono z 12000 do 10600 złotych. Podkomorzy chełmski nie zdążył jednak skorzystać $z$ otrzymanych wówczas nadań. W dniu 24 stycznia $1588 \mathrm{r}$. podpisał jeszcze $z$ innymi obecnymi na sejmie senatorami i posłami nobilitację Jana Januszowskiego. Nie żył już jednak 3 lutego 1588 r., gdy wakujące po nim podkomorstwo chełmskie otrzymał Paweł Orzechowski. Wacław Uhrowiecki, 
podobnie jak jego starszy brat Marcin, był różnowiercą wyznającym kalwinizm. $Z$ małżeństwa $z$ poślubioną na początku lat siedemdziesiątych XVI w. Barbarą Ossolińską pozostawił dwóch synów - Jana i Andrzeja oraz córkę Zofię, wydana przed rokiem 1595 za starostę grabowieckiego Jerzego Cieciszowskiego h. Kolumna9.

Ojcem bohaterki niniejszego artykułu był Mikołaj Uhrowiecki, trzeci, najmłodszy syn podstolego chełmskiego Jana i Anny z Zamoyskich. O ile obaj jego starsi bracia przyszli na świat w latach trzydziestych XVI w., o tyle można sądzić, że Mikołaj urodził się na początku następnego dziesięciolecia. $Z$ fortuny po ojcu przypadły mu wsie Pniówno i Sobibór. Początkowo gospodarował na roli, spławiając do Gdańska 20 łasztów wańczosu i klepki w 1572 r. oraz 12 łasztów zboża w roku 1574. W połowie lat siedemdziesiątych XVI stulecia zdecydował się jednak na wejście do służby Jana Zamoyskiego. Ten ostatni powierzył mu zarząd świeżo otrzymanego (w 1574 r.) starostwa knyszyńskiego na Podlasiu. W dobie wojny o Inflanty $z$ lat 1579-1582 Mikołaj Uhrowiecki służył wojskowo. Co ciekawe, sławę i uznanie współczesnych zdobył jako dowódca rot pieszych. W czasie oblężenia Pskowa w 1581 r. dowodził liczacym ponad 600 ludzi pułkiem (nazywanym rota) szlacheckiej piechoty. W nagrodę za udział w wojnie $z$ Moskwą otrzymał

9 Por. AGAD, MK 100, f. 122v-124a (pożyczka od S. Miłoszewskiego); MK 123, f. 904 (nominacja na podkomorstwo chełmskie $z$ dnia 14 IX 1581 r.); MK 133, k. 235v-236 (nadanie ceł włocławskich); k. 237-237v (nadanie ceł ruskich); MK $134, \mathrm{k} .68 \mathrm{v}$ (podpis Wacława na akcie nobilitacji Jana Januszowskiego); RTAW, s. 217; Posłowie ziemscy koronni 1493-1600 [dalej: Posłowie koronni], oprac. W. Uruszczak, I. Kaniewska, M. Ferenc, J. Byliński, red. I. Kaniewska, Warszawa 2013, s. 175, 205, 214, 260, 278, 290, 308; Urzędnicy bełscy, nr 1269; Stanisław Gostomski do Jana Zamoyskiego, Chełm 7 V 1578, AJZ, t. I, s. 217-218; Wacław Uhrowiecki do Jana Zamoyskiego, Sielec 14 VI 1578, ibidem, s. 224-225; Zamoyskiego list okólny, Kraków 12 V 1584, AJZ, t. III (1582-1584), wyd. J. Siemieński, Warszawa 1913, s. 293-294 (tu błędna informacja, że wspomniany wśród adresatów podkomorzy chełmski to nieżyjacy już M. Sienicki); Jan Zamoyski do miasta Gdańska, Zamość 12 IV 1587, AJZ, t. IV (1585-1588), wyd. K. Lepszy, Kraków 1948, s. 112; Jan Zamoyski do miasta Gdańska, Zamość 11 V 1587, ibidem, s. 118-119; E. Dubas-Urwanowicz, op. cit., s. 472, 592; J. Bukows ki, Dzieje reformacyi w Polsce od wejścia jej do Polski aż do jej upadku, t. I, Kraków 1883, s. 417; W. Czarnecki, op. cit., s. 23; APL, ChGZ, nr 13, s. 481-482 (tu Zofia Uhrowiecka, żona Jerzego Cieciszowskiego, jako rodzona siostra Jana, syna zmarłego Wacława Uhrowieckiego); MK 133, k. 591v-592 (23 II 1595 r. król na prośbę Jana Zamoyskiego wyraża zgodę na to, aby dożywocie na wsi Miączyn przysługiwało nie tylko Jerzemu Cieciszowskiemu, lecz także jego żonie, Zofii z Uhrowieckich). Por. też wyżej przyp. 8. 
w dożywocie na mocy przywileju królewskiego datowanego w Rydze 26 marca 1582 r. dzierżawę ropczycką (zwaną także ówcześnie dzierżawą górską) w województwie sandomierskim. W tym samym roku Jan Zamoyski powierzył Uhrowieckiemu funkcję podstarościego w stołecznym mieście Krakowie. W kwietniu 1583 r. Mikołaj Uhrowiecki został mianowany burgrabią krakowskim. Będąc podstarościm w Krakowie, ojciec naszej bohaterki odegrał istotna, aczkolwiek niezbyt chlubna rolę w sprawie Samuela Zborowskiego. Skrupulatnie wykonując rozkazy Zamoyskiego, roztoczył bowiem ścisły i bardzo rygorystyczny nadzór nad uwięzionym magnatem, a następnie przygotował i przeprowadził jego egzekucję 26 maja 1584 r. W sierpniu tego samego roku Uhrowiecki scedował urząd burgrabiego krakowskiego na rzecz starosty dobczyckiego Sebastiana Lubomirskiego. Najpóźniej w sierpniu 1585 r., gdy Jan Zamoyski odstapił starostwo krakowskie Mikołajowi Zebrzydowskiemu, najmłodszy $z$ braci Uhrowieckich przestał też pełnić urząd podstarościego w Krakowie. W 1587 r. Mikołaj Uhrowiecki dowodził oddziałami wojskowymi przyprowadzonymi przez Zamoyskiego na pole elekcji pod Warszawa. Wygrana wojna o tron polski i objęcie władzy przez popieranego przez pana na Zamościu Zygmunta III Wazę zdawała się być okolicznościa nad wyraz pomyślną zarówno dla zwycięskiego wodza, jak i dla jego politycznych przyjaciół i stronników. Kanclerz wielki koronny musiał być zadowolony $z$ dotychczasowych usług oddawanych mu przez Mikołaja, skoro w $1588 \mathrm{r}$. brał pod uwagę rozpoczęcie zabiegów o nadanie mu bogatego starostwa kamionackiego w województwie ruskim ${ }^{10}$.

10 Por. APL, ChGZ, nr 5, s. 135-136, 143-144 (tu Mikołaj jako dziedzic na Pniównie i Sobiborze); RTAW, s. 295, 409; Mikołaj Uhrowiecki do Jana Zamoyskiego, Knyszyn 9 V 1575, AJZ, t. I, s. 91-92; Mikołaj Uhrowiecki do Jana Zamoyskiego, Kraków 5 XI 1583, AJZ, t. III, s. 228-229; W. Tygie1s ki, Epistolografia staropolska jako źródło do badania mechanizmów politycznych, „Odrodzenie i Reformacja w Polsce” 1988, t. XXXIII, s. 72-73; id e m, W poszukiwaniu patrona, „Przegląd Historyczny” 1987, t. LXXVIII, z. 2, s. 207; B. Pa procki, op. cit., s. 612, 891; K. Niesiecki, op. cit., t. IX, s. 193; K. Górski, Historya piechoty polskiej, Kraków 1893, s. 34; W. Dworzaczek, op. cit., s. 408; W. Bondyra, op. cit., s. 137, 140, 150; AGAD, MK 123, f. 977v-978v (nadanie Uhrowieckiemu miasta Góry z przyległościami); Archiwum Narodowe w Krakowie [dalej: ANK], Castriensia Cracoviensia Relationes, nr 653, s. 591 (intromisja Uhrowieckiego na urzad burgrabiego krakowskiego - 18 IV 1583 r.); nr 654, s. 1293-1295 (rezygnacja z burgrabiostwa krakowskiego na rzecz Sebastiana Lubomirskiego - 26 VIII 1584 r.); Urzędnicy województwa krakowskiego XVI-XVIII wieku. Spisy, oprac. S. Cynarski i A. Falniowska-Gradowska, red. A. Gąsiorowski, Kórnik 1990, nr 934; 
W końcu stycznia 1588 r. zmarł starszy brat Mikołaja, podkomorzy chełmski Wacław Uhrowiecki. Staroście ropczyckiemu przypadła opieka (sprawował ja $z$ drugim bratem Marcinem) nad niepełnoletnimi synami zmarłego, Janem i Andrzejem. Już 12 lutego 1588 r. król Zygmunt III przeniósł na Mikołaja prawo do dzierżawy ceł ruskich (miał je trzymać wspólnie z Pawłem Orzechowskim), które pierwotnie nadano jego zmarłemu bratu. Dnia 25 maja następnego roku król potwierdził ten przywilej, obniżając jednocześnie kwotę czynszu, którą dzierżawcy mieli wnosić do skarbu z 10600 na 8267 złotych rocznie. Przez osiem kolejnych lat (od 20 lipca 1589 do 20 lipca 1597 r.) Mikołaj Uhrowiecki i Paweł Orzechowski administrowali więc wspólnie dochodowymi cłami ruskimi. Niemal w tym samym czasie (22 kwietnia 1589 r.) Uhrowiecki ustapił $z$ dzierżawy ropczyckiej na rzecz Jana Ossowskiego, ówcześnie kasztelana połanieckiego. W kwietniu 1591 r. Mikołaj Uhrowiecki został mianowany grodowym starosta chełmskim. Znacznie wzmocniło to jego pozycję zarówno wśród szlachty rodzinnej ziemi, jak i w otoczeniu Jana Zamoyskiego. W marcu 1593 r. został po raz pierwszy wybrany posłem na sejmiku w Chełmie. Wziął też udział w obradach sejmu zwyczajnego w Warszawie (4 maja - 15 czerwca 1593 r.). W czasie dyskusji nad wyborem marszałka sejmowego wystapił przeciwko kandydaturze starosty śniatyńskiego Mikołaja Jazłowieckiego. W ostatnim dniu obrad podpisał zaś zgodę na wyjazd króla do Szwecji. Po raz kolejny Uhrowiecki posłował na sejm zwyczajny w Warszawie obradujacy od 10 lutego do 26 marca 1597 r. W trakcie obrad zabierał głos w sprawie upominków tatarskich. Bronił też Jana Zamoyskiego przed zarzutem, że zatrzymuje dla siebie podarunki od hospodara mołdawskiego Jeremiasza Mohyły. Oskarżał wreszcie niektórych posłów o sprzyjanie arcyksięciu Maksymilianowi i hamowanie obrad sejmowych. Dnia 11 marca zostal wybrany deputatem do komisji senatorsko-poselskiej mającej opracować projekty konstytucji. Był jednym $z$ nielicznych posłów, którzy pozostali w Warszawie po rozejściu się sejmu bez konkludowania jego obrad. W dniu 25 marca 1597 r. w obecności króla prosił o pismo do braci, że on chciał dobra Rzeczypospolitej, a nie jak inni, którzy nad wszystkie inne sprawy przedkładali prywatę i nie chcieli ratować państwa. Jako poseł ziemi chełmskiej Mikołaj Uhrowiecki wziął też udział

L. Siemień ski, Pamiętniki o Samuelu Zborowskim, Poznań 1844, s. 51-57; E. Dubas-Urwanowicz, op. cit., s. 402-403, 618. 
w obradach sejmów 1598 i 1600 r. Nie zaznaczył jednak niczym szczególnym swojego w nich udziału ${ }^{11}$.

Warto zwrócić uwagę na to, jak bardzo zmieniły się relacje łączące ojca naszej bohaterki $z$ jego patronem i protektorem, Janem Zamoyskim. W ostatnim dziesięcioleciu XVI w. Mikołaj Uhrowiecki nie był już sługa i klientem pana na Zamościu. Uważni obserwatorzy sceny politycznej uważali go w owym czasie za jednego $z$ najbliższych współpracowników i powierników kanclerza wielkiego koronnego. Zmarły 3 czerwca 1605 r. Jan Zamoyski powierzył też Uhrowieckiemu (obok Stanisława Żółkiewskiego, Mikołaja Zebrzydowskiego, Marka Sobieskiego i Jerzego Zamoyskiego) opiekę nad jedynym synem Tomaszem i dobrami ordynacji zamojskiej. Starosta chełmski nie odgrywał jednak w tym gronie pierwszoplanowej roli, a zajęty własnymi sprawami, nie angażował się zbytnio w sprawowanie opieki nad drugim ordynatem i jego rozległymi dobrami. Musiał jednak interweniować w momencie, kiedy wojewoda krakowski Mikołaj Zebrzydowski zaczął dość bezceremonialnie czerpać na własne potrzeby $z$ majątku ich wspólnego pupila. W maju 1606 r. doszło w Zamościu do spotkania wszystkich żyjących opiekunów (Marek Sobieski zmarł 10 listopada 1605 r.), podczas którego Żółkiewski, Zamoyski i Uhrowiecki zabronili Zebrzydowskiemu wyzyskiwania zasobów ordynackich do zaciagania wojska do walki $z$ królem. Warto tu wspomnieć, że spotkanie to odbyło się w okresie narastającego napięcia politycznego w Rzeczypospolitej, a sam Uhrowiecki pojechał do Zamościa (być może razem $z$ wojewodą krakowskim) prosto $z$ odbytego w kwietniu zjazdu opozycyjnej szlachty w Stężycy. Zjazd ten został zwołany datowanym na 23 lutego 1606 r. uniwersałem wydanym (przy czynnym współudziale wojewody krakowskiego) przez generalny sejmik małopolski w Nowym Mieście Korczynie. W zjeździe stężyckim Mikołaj Uhrowiecki wziął udział wraz z kilkunastoosobową grupa związanej niegdyś $z$ kanclerzem wielkim koronnym szlachty chełmskiej. Uczestnicy zjazdu w Stężycy wydali kolejny uniwersał, wzywając szlachtę do pojawienia się pod Lublinem w początkach czerwca 1606 r. Na zjazd ten starosta chełmski przyprowadził stukonną choragiew husarską

11 Por. AGAD, MK 133, k. 376v-377 (cesja Góry i Ropczyc na rzecz Jana Ossowskiego); k. 397v-398 (potwierdzenie nadania ceł ruskich z 25 V 1589 r.); MK 134, k. 158-159 (nadanie cel ruskich z 12 II 1588 r.); Urzędnicy bełscy, nr 1431; Posłowie koronni, s. 358, 387, 397, 408; Dyaryusz sejmu warszawskiego 1597 roku, [w:] Scriptores Rerum Polonicarum, t. XX, wyd. E. Barwiński, Kraków 1907, s. 102, 119-121, 394, 398, 520. 
oraz kilkudziesięciu szlachty ze swojego powiatu. Na jego wniosek dokładnie wyznaczono koło oraz postanowiono, że poczty zbrojne stana w pewnym oddaleniu od miejsca obrad. Przemawiajacc 11 czerwca w imieniu szlachty chełmskiej, nie atakował bezpośrednio króla, ale wyraził zaniepokojenie radami udzielanymi Zygmuntowi III przez jego zaufanych doradców. Proponował też przygotowanie i przedstawienie królowi szlacheckich egzorbitancji. Zjazd lubelski wezwał cała szlachtę na rokosz pod Sandomierz, wyznaczając jego poczatek na 6 sierpnia 1606 r. Uhrowiecki z pełnym przekonaniem przystapił do rokoszu. Stawił się pod Sandomierzem i podpisał akt konfederacji generalnej zawiąanej 12 sierpnia 1606 r. Cieszył się uznaniem mas szlacheckich i był uważany za jednego $z$ przywódców rozpoczętego właśnie rokoszu. W czasie zjazdu sandomierskiego poparł wniosek wojewodzica podolskiego Jakuba Sienieńskiego, aby powierzyć Mikołajowi Zebrzydowskiemu funkcję hetmana rokoszowego. Uhrowiecki pomagał też wojewodzie krakowskiemu w innych, ważnych dla niego sprawach. Nie można wykluczyć tego, że właśnie działania podjęte przez starostę chełmskiego (wbrew stanowisku Stanisława Żółkiewskiego i Jerzego Zamoyskiego, którzy przeszli na pozycje regalistyczne) umożliwiły Zebrzydowskiemu wykorzystanie artylerii zamojskiej i milicji ordynackiej przeciwko siłom wiernym Zygmuntowi III. Można przypuszczać, że Mikołaj Uhrowiecki wytrwał w szeregach rokoszan aż do ugody janowieckiej z 7 października 1606 r. Wiosna następnego roku Uhrowiecki uzyskał mandat poselski na sejmiku ziemi chełmskiej i wziął udział w obradach sejmu zwyczajnego, który obradował w Warszawie od 7 maja do 16 czerwca 1607 r. Nic więcej o jego działalności publicznej nie wiadomo ${ }^{12}$.

W przeciwieństwie do swoich starszych braci, wyznawców kalwinizmu, Mikołaj Uhrowiecki był katolikiem. Jego przekonania religijne legły zapewne u podstaw decyzji o wysłaniu Jana i Andrzeja Uhrowieckich, synów kalwinisty Wacława do prowadzonej przez jezuitów uczelni w bawarskim Ingolstadt. Obaj podkomorzyce chełmscy rozpoczęli tu studia w 1593 r. Wkrótce jednak starszy - Jan przeniósł się do protestanckiej szkoły w Altdorfie koło

${ }^{12}$ Por. V. Urbaniak, Zamoyszczycy bez Zamoyskiego. Studium dekompozycji ugrupowania politycznego, Warszawa 1995, s. 3, 11, 16, 36, 39, 41, 62, 66, 69, 99, 141, 144, 145; J. Macis zew ski, Wojna domowa w Polsce (1606-1609). Studium $z$ dziejów walki przeciwko kontrreformacji, cz. 1 (Od Stężycy do Janowca), Wrocław 1960, s. 143, 145, 167, 170, 193, 264, 286, 297; W. B ondy ra, op. cit., s. 145 . 
Norymbergi. Andrzej, który pozostał w Ingolstadt, zadłużył się $\mathrm{u}$ miejscowych mieszczan i nie był $\mathrm{w}$ stanie spłacić zaciagnniętych pożyczek. Poproszony o pomoc Jan wywiózł więc w 1595 r. potajemnie młodszego brata do Altdorfu, pozostawiając $z$ niczym jego wierzycieli. W tej sytuacji, w grudniu 1596 r. władze uniwersytetu w Ingolstadt zwróciły się do starosty chełmskiego $z$ prośbą o uregulowanie długów bratanka ${ }^{13}$.

Możemy przypuszczać, że nawet jeśli Mikołaj Uhrowiecki spłacił wierzycieli Andrzeja, to $z$ pewnościa potracił sobie należność $z$ dochodów $z$ dóbr pupila. Starosta chełmski był bowiem człowiekiem bardzo zapobiegliwym i systematycznie powiększał swój majątek. Jak już wspomniano, w latach siedemdziesiątych XVI w. był właścicielem odziedziczonych po ojcu wsi Pniówno i Sobibór. Tę drugą wieś w bliżej nieokreślonym czasie odstąpił jednak bratu Marcinowi, otrzymując w zamian część wsi Krobonosza. W 1588 r. przeprowadził frymark $z$ Elżbietą Skorucianką, córka nieżyjącego już Marcina Skoruty, działająca w asyście swoich prawnych opiekunów, dając jej Pniówno i część Krobonoszy (oraz dopłatę w gotówce), w zamian za jej dziedziczne wsie Dzdzane (dziś Żdżanne), Wierzchowiny i Dypułtycze Ruskie. Po objęciu urzędu starosty chełmskiego w 1591 r. Mikołaj Uhrowiecki ze zdwojoną energia przystąpił do powiększania swoich dóbr ziemskich, kupując kolejne wsie w granicach swojej jurysdykcji. W 1600 r. odziedziczył wraz $z$ Janem i Andrzejem Uhrowieckimi wszystkie posiadłości po zmarłym bezpotomnie bracie Marcinie. W roku następnym wymienił ze swoimi bratankami połowę wsi Łuków (Łukówek), która przypadła mu w udziale po zmarłym kasztelanie chełmskim na ich dziedziczną wieś Sielec (Sielce) z zamkiem i folwarkiem. Przy tej okazji możemy jednoznacznie stwierdzić, że fundatorem bastejowego zamku w Sielcu był podkomorzy chełmski Wacław Uhrowiecki, a Mikołaj jedynie dokończył rozpoczęta przez brata budowę tej warowni. Nie wchodząc już w dalsze szczegóły, poprzestańmy na stwierdzeniu, że starosta chełmski pozostawił swoim spadkobiercom dwa klucze dóbr w ziemi chełmskiej - radziechowski i dzdzański. W skład pierwszego wchodziły wsie Radziechów, Binduga, Maszów, Podstawie, Rakowy Most seu Rakowiec, Sztuń, Czmykos seu Wola,

13 Por. Posłowie koronni, s. 358; J. Maciszew ski, op. cit., s. 286; W. B ondyra, op. cit., s. 150 (tu o wybudowaniu zamku w Sielcu przez Mikołaja Uhrowieckiego), 153; P. Czaplewski, Polacy na studiach w Ingolsztacie, Poznań 1914, s. 105 . 
Wysock, Zamłynie, Zarzecze i Ziemlica. Na majętność dzdzańską składały się natomiast wsie Dzdzane, Wierzchowiny, Dypułtycze Ruskie, Weremowce oraz nowo założona wioska Uher. Dzieci Mikołaja Uhrowieckiego odziedziczyły po ojcu także niezwiązana $z$ żadnym kluczem wieś Sielec z zamkiem. Dodajmy do tego, że oprócz starostwa chełmskiego, Uhrowiecki użytkował również należącą do domeny monarszej wieś Dypułtycze Królewskie. Jak więc widzimy, była to już prawdziwie „pańska” fortuna, pozwalająca zaliczyć właściciela sieleckiego zamku do grona najzamożniejszych posesjonatów w ziemi chełmskiej ${ }^{14}$.

Mikołaj Uhrowiecki ożenił się pod koniec lat osiemdziesiątych XVI w. z Katarzyną Potocką h. Pilawa, córką chorążego kamienieckiego Andrzeja i Krystyny z Hermanowa Włodkówny h. Prawdzic. Wiemy o niej jedynie tyle, że 6 kwietnia 1590 r., będąc już żona Uhrowieckiego, zrezygnowała za jego zgodą ze swojego dożywocia na królewskiej wsi Olchowiec w powiecie kamienieckim na rzecz Adama Czołhańskiego. Starosta chełmski Mikołaj Uhrowiecki zmarł na początku 1609 r. (przed 30 stycznia). Z małżeństwa z Katarzyna Potocka pozostawił trójkę dzieci - syna Marcina oraz córki Zofię i Krystynę ${ }^{15}$.

Najstarszy $z$ rodzeństwa był bez watpienia Marcin. W chwili śmierci ojca mógł mieć około 20 lat. Starosta chełmski za życia zadbał o przyszłość jedynaka, wysyłając go do Akademii Zamojskiej, gdzie Marcin uczył się razem $z$ Tomaszem Zamoyskim oraz $z$ dość liczna grupa synów przyjaciół i współpracowników kanclerza

${ }^{14}$ Por. APL, ChGZ, nr 7, s. 489; nr 8, s. 1620-1628, 1638-1644; nr 9, s. 52, 58, 282-283; nr 13, s. 78 (intromisja Mikołaja Uhrowieckiego do wsi Sielec „cum castro et praedio"), 101, 727-728; nr 16, s. 35; nr 18, s. 857, 1006-1014, 11881191, 1301-1302, 1313-1314; M.J. Kaw ałko, op. cit., s. 113 (tu Uhrowiecki jako tenutariusz Dypułtycz Królewskich).

15 Por. AGAD, MK 133, k. 438-438v (tu Katarzyna z Potoka Uhrowiecka); M. Plewczyńs ki, Potocki Andrzej, [w:] PSB, t. XXVII, Wrocław 1983, s. 768-769 (tu jednak nieprawdziwa informacja, że mężem Katarzyny był starosta chełmski Michał Woroniecki, który nota bene nigdy starosta w Chełmie nie był); APL, ChGZ, nr 9, s. 451-452 (tu Krystyna $z$ Hermanowa, wdowa po chorażym kamienieckim Andrzeju Potockim, ceduje na Mikołaja Uhrowieckiego należna jej wierzytelność od Mikołaja z Dziedziłowa Herburta); Urzędnicy bełscy, nr 1432. Dodajmy w tym miejscu, że autorzy przywołanego spisu, powołując się na wpis do Metryki Koronnej, stwierdzają, że Mikołaj Daniłowicz otrzymał nominację na starostę chełmskiego 30 I 1609 r., ale „nie podano po kim”. Tymczasem w cytowanym przez nich dokumencie wyraźnie napisano, że Daniłowicz otrzymuje nominację po śmierci poprzedniego starosty chełmskiego Mikołaja Uhrowieckiego, który zmarł „hoc tempore". Por. AGAD, MK 154, k. 6v. 
wielkiego koronnego Jana. Kolegami starościca chełmskiego byli w Zamościu m.in. Jan Żółkiewski, Mikołaj Ostroróg, Jakub Sobieski, Mikołaj Potocki, Aleksander Prusinowski i Prokop Leśniowolski. Większość $z$ nich odegrała w przyszłości dość znaczną rolę na scenie politycznej. Szansę na dużą karierę miał również Marcin Uhrowiecki. Przez ojca łączyło go dość bliskie pokrewieństwo $z$ drugim ordynatem zamojskim. Jego matka była natomiast siostra stryjeczna czterech senatorów $z$ rodziny Potockich - wojewody bracławskiego Jana, kasztelana kamienieckiego Andrzeja oraz kolejnych wojewodów bracławskich - Jakuba i Stefana. Zwłaszcza $z$ tym ostatnim (trzej pierwsi zmarli w latach 1609-1613) utrzymywał później Marcin dość bliskie stosunki. Po ojcu odziedziczył młody starościc „pańska” fortunę w ziemi chełmskiej. Po matce przejął miasteczko Sidorów z zamkiem oraz kilkoma przyległymi wsiami w powiecie halickim blisko granicy Podola. W źródłach określano go jako pana na Radziechowie, Maszowie, Sidorowie, Dzdzanem i Sielcu. Dobre koligacje i spory majatek odziedziczony po rodzicach stanowiły niewatpliwe atuty Marcina. Nie zostały jednak przez niego odpowiednio wykorzystane. Trzeba bowiem wyraźnie stwierdzić, że starościc chełmski zawiódł pokładane w nim nadzieje i nie zdołał utrzymać pozycji osiagniętej przez ojca. Nie angażował się wcale $\mathrm{w}$ działalność publiczna, a jego poczynania natury finansowej doprowadziły w rezultacie do majatkowej katastrofy. Zanim to nastapiło, Marcin zdążył wyposażyć obie siostry. W 1612 r. oddał bowiem Zofię do klasztoru lubelskich brygidek, a dwa lata później wydał Krystynę za podkomorzego mielnickiego Kaspra Dembińskiego. W następnych latach młody Uhrowiecki żył jednak ponad stan, zaciagał coraz to nowe pożyczki, jak również zadłużał i zastawiał swoje dobra. W 1617 r. zmuszony był sprzedać Dzdzane i Wierzchowiny miecznikowi wołyńskiemu Janowi z Osieka Badzyńskiemu. W lutym 1619 r. Uhrowiecki sprzedał z kolei za 160000 florenów całą włość radziechowską (w sumie 11 osad) chorążemu koronnemu Stefanowi Snopkowskiemu. Jak można przypuszczać, Snopkowski nie wypłacił Uhrowieckiemu od razu całej uzgodnionej sumy, a to, co trafiło do rąk starościca, poszło od razu na spłacenie części starych długów. Już 22 czerwca 1619 r., a więc zaledwie cztery miesiące później, Jan Bądzyński objął bowiem w realne posiadanie również pozostałe wsie klucza dzdzańskiego: Dypułtycze, Uher i Weremowce. Wsie te od pewnego czasu trzymał modo obligatorio Mikołaj Ossoliński w sumie 25000 złotych. 
Miecznik wołyński wykupił od niego ten zastaw, a Marcin Uhrowiecki, nie mając możliwości spłacenia Bądzyńskiego, odprzedał mu również te dobra. Warto przy tej okazji wspomnieć, że Jan Bądzyński był zaufanym sługa i dworzaninem potężnego magnata kresowego, wojewodzica wołyńskiego Janusza ks. Ostrogskiego, znanego $z$ hojnej ręki wobec swoich domowników. Nie można więc wykluczyć, że jego protektor wspomógł go finansowo, umożliwiając mu w konsekwencji nabycie całej majętności dzdzańskiej ${ }^{16}$.

Po sprzedaży głównego zrębu majętności ojcowskich w rękach Marcina Uhrowieckiego pozostała w ziemi chełmskiej jedynie wieś Sielec $z$ zamkiem. Nie jest natomiast pewne, czy był on w owym czasie właścicielem włości sidorowskiej. Wiemy bowiem, że Sidorów w XVII w. należał do rodziny Kalinowskich h. Kalinowa, właścicieli pobliskiego Husiatyna. Nie wiemy natomiast, czy dobra te kupił starosta kamieniecki Walenty (zm. 1620), czy też dopiero jego syn Marcin (zm. 1652), wojewoda czernihowski i hetman polny koronny. W każdym razie jest kwestią bezsporna, że przed swoja śmiercią Uhrowiecki wyzbył się również i tego majątku. Miał także ogromne kłopoty z utrzymaniem się w posesji Sielca. Zainteresowany nabyciem tej wsi, a zwłaszcza tamtejszego zamku był krewny Marcina, ówcześnie pisarz polny koronny i starosta feliński Stefan Potocki. Zawarł on nawet ze starościcem chełmskim w $1617 \mathrm{r}$. umowę dotycząca kupna Sielca pod zakładem 100000 florenów, ale ostatecznie nie weszła ona w życie. Nie mogąc się doczekać od Potockiego pieniędzy, w 1619 r. Marcin Uhrowiecki sprzedał Sielec wraz z zamkiem i wszystkimi przyległościami Zofii z Orzechowskich Strusiowej, żonie Mikołaja $z$ Komorowa Strusia, wówczas starosty chmielnickiego. Jeszcze w tym samym roku Strusiowa

${ }^{16}$ Por. V. Urbaniak, op. cit., s. 10; APL, ChGZ, nr 16, s. 35; nr 17, s. 10791081 (tu o wydaniu Krystyny Uhrowieckiej za Kaspra Dembińskiego); nr 18, s. 149-150, 226, 319-322, 1006-1014 (tu o sprzedaży klucza radziechowskiego Stefanowi Snopkowskiemu), 1188-1191 (rozgraniczenie Dzdzanego i Wierzchowin od Sielca i wzmianka o sprzedaży tych wsi w 1617 r.), 1301-1302 (intromisja Jana Bądzyńskiego do wsi Dypułtycze, Uher i Weremowce); J.K. Marczewski, Ad duos illustres appendix: córki szlacheckie Kasprowi Niesieckiemu i Adamowi Bonieckiemu nieznane, „Archiwa, Biblioteki i Muzea Kościelne” 2010, t. XCIII, s. 107 (tu o Zofii Uhrowieckiej); H. Kowalska, Snopkowski Stefan, [w:] PSB, t. XXXIX, Warszawa-Kraków 1999-2000, s. 407-408 (tu jednak brak jakiejkolwiek wzmianki o nabyciu przez Snopkowskiego dóbr radziechowskich); Z. Anusik, Krótkie życie $i$ niespodziewana śmierć młodego magnata. Janusz Paweł ks. Ostrogski i jego testament z 6 sierpnia 1619 roku, „Przegląd Nauk Historycznych” 2020, R. XIX, nr 1, s. 230, 234. 
objęła tę wieś w realne posiadanie, a następnie wydzierżawiła ją Jerzemu Błędowskiemu. Wyzbywszy się wszystkich swoich dóbr ziemskich, zbankrutowany Marcin Uhrowiecki nie pożył już długo. Zmarł w wieku około 30 lat, w końcu 1621 lub też na początku 1622 r. Rodziny nie założy $1^{17}$.

O siostrze Marcina Uhrowieckiego Zofii możemy powiedzieć jedynie tyle, że w 1612 r. zjawiła się w klasztorze lubelskich brygidek. W 1614 r. przywdziała habit zakonny, w 1615 r. złożyła profesję, a została konsekrowana w roku 1618. Zmarła, majac około 60 lat, w roku $1655^{18}$. Druga siostra starościca chełmskiego była bohaterka niniejszego studium - Krystyna. Urodziła się ona prawdopodobnie w połowie lat dziewięćdziesiątych XVI stulecia, a imię otrzymała zapewne po swojej babce macierzystej, Krystynie z Hermanowa Włodkównie, żonie Andrzeja Potockiego. W 1614 r. starszy brat postanowił wydać ja za mąż. Dnia 30 lipca tego roku zawarł w Lublinie umowę w sprawie małżeństwa Krystyny $z$ podstarzałym już wdowcem, podkomorzym mielnickim Kasprem Dembińskim. Starościc chełmski dał siostrze w posagu 20000 florenów zabezpieczonych na miasteczku Sidorów oraz wsiach Grzywa i Zielona Łąka. Możemy przypuszczać, że wkrótce potem Dembiński albo otrzymał obiecana gotówkę, albo też Uhrowiecki oddał mu w użytkowanie swoje dobra po matce. W każdym razie już w na początku października 1614 r. podkomorzy mielnicki skwitował w Lublinie szwagra $z$ posagu, a Krystyna zeznała ustapienie $z$ dóbr ojczystych i macierzystych. Zgodnie ze zwyczajem epoki małżonek oprawił jej posag w podwójnej wysokości na połowie swoich dóbr ${ }^{19}$.

Kasper Dembiński h. Rawicz, mąż Krystyny Uhrowieckiej, był synem kasztelana krakowskiego Walentego i jego pierwszej żony, Elżbiety Kuczkowskiej. Miał bardzo liczne rodzeństwo. Był także kilkadziesiąt lat starszy od starościanki chełmskiej. Podobnie jak jej ojciec, będac rotmistrzem w armii koronnej, walczył w wojnach z Moskwa za panowania Stefana Batorego. W 1580 r. otrzymał

17 Por. APL, ChGZ, nr 18, s. 1358-1359 (intromisja Zofii Strusiowej do Sielca), 1483-1485 (skarga Stefana Potockiego na niedotrzymanie umowy przez Marcina Uhrowieckiego), 1649 (tu Zofia Strusiowa jako dziedziczka, a Jerzy Błędowski jako dzierżawca Sielca).

18 Por. J.K. Marczewski, op. cit., s. 107.

19 Por. APL, ChGZ, nr 17, s. 1079-1081; A. Boniecki, op. cit., t. IV, Warszawa 1901, s. 213 (tu informacja, że Dembiński zapisał żonie oprawę w wysokości 50000 florenów). Być może więc suma posagowa Krystyny została ostatecznie zwiększona do 25000 złotych. 
urząd podkomorzego mielnickiego. W czasie trzeciego bezkrólewia opowiedział się po stronie arcyksięcia Maksymiliana. Posłował $z$ województwa podlaskiego na sejm 1589 r. Przed sejmem zwyczajnym 1590 r. został wybrany posłem przez przeciwników Jana Zamoyskiego na rozdwojonym sejmiku w Proszowicach. Antykanclerski komplet posłów nie został jednak dopuszczony do obrad tego sejmu. Jako reprezentant ziemi mielnickiej Dembiński wziął za to udział w sejmie obradujaccym na przełomie 1590 i 1591 r. Posłował również na sejm 1600 r., reprezentując tym razem szlachtę krakowska. W dobie rokoszu sandomierskiego podkomorzy mielnicki czynnie zaangażował się $\mathrm{w}$ działania antyregalistycznej opozycji. W działach dóbr po ojcu, przeprowadzonych w 1586 r., przypadły mu wsie Piotrowice, Zakrzów, Skorupice i Błonie w województwie krakowskim. Jego pierwszą żona, poślubiona w 1580 r., była Maryna (Marianna) Kopciówna h. Kroje, córka Iwana (Jana), która wniosła mu w posagu duże dobra Horodyszcze w ziemi mielnickiej. $Z$ małżeństwa tego Kasper Dembiński miał trzy córki: Agnieszkę, Zofię i Dorotę. Najstarsza z nich, Agnieszka już w 1598 r. została wydana za stolnika (w przyszłości podkomorzego) sochaczewskiego Jana Trzcińskiego h. Rawicz. Otrzymała 30000 złotych posagu i zeznała w grodzie warszawskim abrenuncjację $z$ dóbr ojczystych i macierzystych. Zmarła w 1611 r., pozostawiajac po sobie dwie córki. Młodsze podkomorzanki mielnickie stały się natomiast bohaterkami głośnego skandalu obyczajowego, który wstrząsnął Rzeczpospolita na krótko przed drugim małżeństwem ich ojca ${ }^{20}$.

Średnia córka Kaspra Dembińskiego, Zofia w początkach $1611 \mathrm{r}$. została wydana za mąż za Aleksandra Koniecpolskiego h. Pobóg. Wesele i dopełnienie małżeństwa zostało jednak odłożone w czasie, a Zofia pozostała przy mieszkającej w Krakowie matce aż do jej śmierci w lipcu 1611 r. Już w maju tego roku Koniecpolska przesłała jednak do Rzymu za pośrednictwem zakonu jezuitów prośbę o zwolnienie ją $z$ danego słowa i pozwolenie na złożenie ślubów zakonnych. Pod pretekstem przeczekania żałoby po matce Zofia i jej młodsza siostra Dorota zostały powierzone opiece bernardynek z klasztoru św. Agnieszki na Stradomiu. Sam Aleksander prosił

${ }^{20}$ Por. B. Paprocki, op. cit., s. 543; K. Niesiecki, op. cit., t. III, Lipsk 1839, s. 321; F. Siarczyńs ki, Obraz wieku panowania Zygmunta III, króla polskiego i szwedzkiego, cz. 1, Lwów 1828, s. 94-95; A. Boniecki, op. cit., t. IV, s. 213; Posłowie koronni, s. 324, 327, 339, 406; J. Maciszewski, op. cit., s. 262; APL, ChGZ, nr 18, s. 439-443 (tu oblata umowy Kaspra Dembińskiego z Janem Trzcińskim z 1598 r. i zeznanie o ustapieniu z dóbr Agnieszki Dembińskiej). 
o tę opiekę i w październiku 1611 r. osobiście odprowadził żonę do klasztoru. Wkrótce potem obie podkomorzanki mielnickie podjęły decyzję, że zostana zakonnicami. Mimo nalegań ojca, bojąc się, że nie będa mogły wrócić na Stradom, nie wzięły udziału w pogrzebie własnej matki. Koniecpolski próbował za wszelką cenę wydobyć żonę $z$ klasztoru i wymógł na biskupie krakowskim Piotrze Tylickim wysłanie do bernardynek specjalnej komisji. W chwili jej przybycia Zofia przywdziała jednak szaty zakonne i złożyła przed ołtarzem ślub czystości. W lutym 1612 r. Stolica Apostolska przekazała decyzję w sprawie zwolnienia Koniecpolskiej z przysięgi małżeńskiej sądowi biskupiemu w Krakowie. Nie czekając na jego orzeczenie, w nocy z 16 na 17 kwietnia 1612 r. (w czasie wielkiego tygodnia, co było okolicznością dodatkowo go obciążająca) Aleksander najechał na klasztor św. Agnieszki i uprowadził stamtąd zarówno żonę, jak i jej młodszą siostrę, gdyż obie panny nie pozwoliły się rozdzielić. W Koniecpolu wziął z Zofią ponowny ślub i tam zamieszkał. Tymczasem już 4 maja biskup Tylicki proklamował ekskomunikę Aleksandra Koniecpolskiego. Sprawca napadu na klasztor został również pozwany na sąd sejmowy, który skazał go na infamię. W 1613 r. Zofia urodziła syna Jana Przedbora, ale zmarła wkrótce potem. Po jej śmierci Koniecpolski, który odwołał się tymczasem od wydanego zaocznie wyroku, energicznie, aczkolwiek bezskutecznie zabiegał o wydzielenie przez teścia działów należnych jego synowi, Dorocie Dembińskiej oraz córkom nieżyjącej już Agnieszki Trzcińskiej. Planował nawet podobno zbrojny zajazd dóbr należących niegdyś do matki jego zmarłej żony. Podkomorzy mielnicki nie myślał rzecz jasna o żadnych ustępstwach. Ożeniwszy się właśnie po raz drugi, nie zamierzał dzielić się $z$ nikim majątkiem po pierwszej żonie. $Z$ zadowoleniem przyjął też ostateczny wyrok banicji i infamii na Koniecpolskiego, zatwierdzony w 1615 r. przez króla Zygmunta III. W następstwie obu tych zdarzeń niesforny zięć Kaspra Dembińskiego zmuszony został bowiem do opuszczenia kraju²1.

${ }^{21}$ Nie wiemy niestety, kiedy Aleksander Koniecpolski wrócił do kraju. Nie znamy też daty jego ślubu z najmłodsza podkomorzanką mielnicka, Dorotą. Na ślub z rodzoną siostrą pierwszej żony uzyskał dyspensę papieska. Stało się to więc w czasie, kiedy udało mu się przebłagać władze duchowne. Klasztorowi św. Agnieszki wypłacił odszkodowanie w wysokości 15000 złotych. Doszedł też do porozumienia z mężami siostrzenic swoich żon - Jerzym Rzeczyckim i Bartłomiejem Bełżeckim, którzy dostali podobno po 30000 złotych. Dzięki interwencji hetmana Stanisława Koniecpolskiego sejm 1625 r. podjął wreszcie uchwałę o uchyleniu ciążącego na 
Podkomorzy mielnicki nie miał dobrej opinii wśród współczesnych. Podejrzewano go o to, że to on właśnie stał za intryga, która doprowadziła do opisanych wyżej wydarzeń. Można przypuszczać, że po śmierci najstarszej córki wpadł na pomysł usunięcia ze sceny obu młodszych poprzez wysłanie ich do klasztoru. Gdyby bowiem zabrakło legalnych spadkobierców pierwszej żony, przy zbiegu bardzo sprzyjających okoliczności, pozostawiony przez nia majątek mógłby pozostać na dłużej w rękach rodziny Dembińskich. Rzecz jasna Kasper Dembiński liczył na to, że $z$ drugiego małżeństwa doczeka się syna. Niestety, jego nadzieje nie miały się spełnić. Krystyna Uhrowiecka urodziła mu bowiem jedynie córkę - Franciszkę Katarzynę. Podkomorzy mielnicki zmarł na początku 1620 r. Młoda wdowa niedługo opłakiwała męża, gdyż już pod koniec tego samego roku poślubiła chorążego lubelskiego Zbigniewa Sienieńskiego h. Dębno ${ }^{22}$.

Drugi mąz Krystyny Uhrowieckiej był potomkiem lubelskiej gałęzi rodu Sienieńskich, dziedziczącej na Chroślinie, Boiskach, Mazanowie, Wałowicach i kilku innych wsiach w powiecie urzędowskim. Jego ojcem był Jan Sienieński, zmarły na początku lat dziewięćdziesiątych XVI w. pan na Chroślinie, syn kasztelanica małogoskiego Wiktoryna i jego drugiej żony, Jadwigi Leskiej. Imienia i nazwiska matki Zbigniewa niestety nie znamy. Wiemy natomiast, że żeniąc się $z$ Krystyną, chorąży lubelski był wdowcem po Annie Leńkównie h. Rawicz, córce kasztelana derpskiego Macieja i Teodory Sapieżanki. $Z$ małżeństwa tego miał piątkę dzieci: synów Pawła i Jana oraz córki Aleksandrę, Katarzynę i Krystynę. Warto odnotować, że Zbigniew Sienieński (podobnie jak Kasper Dembiński) aktywnie uczestniczył w życiu politycznym. Posłował $z$ województwa lubelskiego na pięć sejmów, w latach 1616, 1621, 1624, 1627 i 1629 (sejm nadzwyczajny). Blisko związany z drugim ordynatem Tomaszem Zamoyskim, dzięki jego protekcji i poparciu,

nim wyroku infamii i banicji. $Z$ pierwszej żony miał syna Jana Przedbora. Druga, również młodo zmarła, urodziła mu czworo dzieci: synów Jakuba i Stanisława oraz córki Zofię i Barbarę. Aleksander Koniecpolski zmarł przed 1631 r. Por. Pamiętniki o Koniecpolskich. Przyczynek do dziejów polskich XVII wieku, wyd. S. Przyłęcki, Lwów 1842, s. 162-164, 207-212; Z. Libis zowska, Koniecpolski Aleksander, [w:] PSB, t. XIII, Wrocław-Warszawa-Kraków 1967-1968, s. 512-513; A. B o ni e cki, op. cit., t. XI, Warszawa 1907, s. 80.

${ }_{22}$ Por. A. Boniecki, op. cit., t. IV, s. 213; H. G miterek, Sienieński Zbigniew, [w:] PSB, t. XXXVII, Warszawa-Kraków 1996-1997, s. 194. 
1 maja 1630 r. otrzymał od Zygmunta III nominację na senatorski urząd kasztelana lubelskiego ${ }^{23}$.

Jak pamiętamy, na przełomie 1621 i 1622 r. zmarł jedyny brat Krystyny Uhrowieckiej, Marcin. Chorążyna lubelska, będąc jego główną spadkobierczynią, podjęła próbę ratowania resztek rodowego majątku. W pierwszej kolejności udało się jej doprowadzić do unieważnienia transakcji sprzedaży wsi Sielec z zamkiem, z której Marcin Uhrowiecki zrezygnował na rzecz Zofii z Orzechowskich Strusiowej. Dnia 12 marca 1622 r. Krystyna Sienieńska wykupiła tę posiadłość z zastawu za 6000 florenów od Jerzego i Doroty Błędowskich i od tej pory zamek sielecki wraz z przyległymi dobrami pozostawał już nieprzerwanie w jej rękach. Krystyna Sienieńska zawarła też kilka innych transakcji majątkowych. Przede wszystkim przed 6 kwietnia 1622 r. z siostra Zofia (zakonnica) potwierdziła dokonaną przez brata donację (właściwie sprzedaż) włości radziechowskiej (Radziechów z 10 innymi wsiami) na rzecz chorążego koronnego Stefana Snopkowskiego. Zobowiązała się też zaspokoić pretensje wierzycieli Marcina Uhrowieckiego: Stanisława Wereszczyńskiego, Aleksandra Krzywczyckiego i podkomorzego chełmskiego Jana Skaszewskiego. Przy tej samej okazji Zbigniew Sienieński skwitował żonę z pożyczonych jej wcześniej 1470 florenów i otrzymał od Snopkowskiego zapis na kwotę 3000 florenów. O ile Krystyna Sienieńska nie odważyła się zakwestionować sprzedaży Radziechowa (zarówno zmarły już wiosną 1622 r. chorąży koronny, jak i jego spadkobiercy byli bowiem zbyt potężnymi przeciwnikami), o tyle nie pogodziła się z przejęciem przez miecznika wołyńskiego Jana Bądzyńskiego wszystkich innych dóbr po Marcinie Uhrowieckim w ziemi chełmskiej. Powołując się na prawo bliższości, wspólnie $z$ siostrą Zofią oraz stryjecznymi bratankami Jakubem i Stanisławem Uhrowieckimi (synami podkomorzyca chełmskiego Jana) próbowała zmusić Bądzyńskiego, będącego człowiekiem nowym w ziemi chełmskiej, do odprzedania spornych

${ }^{23}$ Por. Z. Anusik, Krag rodzinny Katarzyny z Sienna Myszkowskiej, podczaszyny lubelskiej (zm. 1619). Studium genealogiczno-obyczajowe, „Przegląd Nauk Historycznych” 2020, R. XIX, nr 2, s. 248-250; idem, Sienieńscy herbu Dębno (lubelska gałaź rodu) w XVI i XVII wieku, „Przegląd Nauk Historycznych” 2021 , R. XX, nr 1, s. 102-103, 130-132; H. G miterek, op. cit., s. 193-194 (tu jednak błędne stwierdzenie, że Zbigniew Sienieński był synem kasztelana halickiego Jana i Zofii Paniowskiej. Brak tu również jakiejkolwiek wzmianki o jego pierwszym małżeństwie i pochodzących $z$ tego małżeństwa dzieciach). 
dóbr. Twierdziła także, że majątki te zostały jej zapisane przez brata, a bezprawne ich użytkowanie przez miecznika wołyńskiego naraziło ja na straty szacowane na 200000 grzywien. Przedmiotem sporu były wsie Dzdzane, Wierzchowiny, Uher, Weremowce i Dypułtycze Ruskie. Jak się jednak wydaje, zabiegi Krystyny o odzyskanie dawnego dziedzictwa Uhrowieckich nie przyniosły żadnych rezultatów. W sporządzonym 1 czerwca 1629 r., na potrzeby wybieranego wówczas poboru, spisie miast i wsi ziemi chełmskiej wszystkie sporne wioski odnotowano bowiem jako własność Jana Bądzyńskiego. W 1624 r. chorażyna lubelska ostatecznie zrezygnowała natomiast $z$ wszelkich pretensji do wsi Krzywa Łaka oraz do młyna we wsi Krzywe (obie wsie stanowiły część klucza sidorowskiego) na rzecz ich posesorów zastawnych, kasztelaniców bełskich Jana i Kaspra Żórawińskich, którzy objęli tę majętność w posiadanie w zamian za pożyczkę udzieloną Marcinowi Uhrowieckiemu ${ }^{24}$.

Tak więc $z$ dużego majątku pozostawionego niegdyś przez ojca Krystyny, małżonkom Sienieńskim udało się ostatecznie przejać jedynie wieś Sielec z zamkiem. O wiele ważniejsze było dla nich jednak uzyskanie intromisji w dobra, na których zabezpieczone były zapisy poczynione na rzecz chorążyny lubelskiej przez jej pierwszego męża. Jeden $z$ tych zapisów Kacper Dembiński zabezpieczył na miasteczku Kolano i wsiach Jabłoń, Pasieki i Kudry w ziemi mielnickiej. W 1624 r. Krystyna Sienieńska podjęła więc starania o przejęcie tych dóbr we własny zarząd. Jej zabiegi zakończyły się jednak niepowodzeniem, gdyż wspomniane wioski stanowiły część klucza horodyskiego, który wniosła Dembińskiemu jego pierwsza żona, Maryna Kopciówna. W ostatecznym rozrachunku, zgodnie

${ }^{24}$ Por. H. G miterek, op. cit., s. 194; AGAD, MK 159, k. 241-241v; APL, ChGZ, nr 19, s. 245; nr 20, s. 305-306 (tu bracia Jakub i Stanisław Uhrowieccy oraz Krystyna Sienieńska pozywaja Jana Bądzyńskiego o dobra po Marcinie Uhrowieckim - rok 1625); nr 21, s. 1565, 1575, 1579; Lubelskie ziemskie, Wieczyste i zobowiazzania [dalej: LZWZ], nr 109, k. 365v-369, 376v-379; Lubelskie grodzkie, relacje [dalej: LGR], nr 54, k. 456-457v; nr 57, k. 573-573v; nr 58, k. 568-568v (tu pozew Krystyny Sienieńskiej oraz Jakuba i Stanisława Uhrowieckich przeciwko Janowi Bądzyńskiemu z 23 VII 1629 r.); Z. Anu sik, Sienieńscy..., s. 131132. Dodajmy, że Stanisław Uhrowiecki w 1629 r. był już członkiem Towarzystwa Jezusowego. Kasper Niesiecki zapisał o nim, co następuje: „umarł w Krakowie u Ś. Piotra, po śmierci w kilka lat znaleziony w grobie w purpurowej todze, co mu Bóg nadgrodził jeszcze tu na ziemi gorace pragnienie, którem żarzył serce do męczeństwa za wiarę, do którego sposobiąc się, wymyślnemi ciało swoje katował mękami, żadnej kommunji nie opuścił, przy którejby nie prosił Boga o te łaskę, żeby był mógł za niego krew swoję przelać”. Por. id e m, op. cit., t. IX, s. 193. 
z litera i duchem prawa, sporne wsie przyznano więc spadkobiercom córek podkomorzego mielnickiego $z$ jego pierwszego małżeństwa (w 1642 r. cała włość horodyska przypadła w udziale dzieciom Aleksandra Koniecpolskiego). Inaczej wyglądała sprawa $z$ zapisem 20000 florenów, który Kasper Dembiński zabezpieczył Krystynie na swoich dziedzicznych wsiach w powiecie ksiąskim w województwie krakowskim. Z zachowanych źródeł wynika, że Sienieńska objęła w realne posiadanie, „jako pani oprawna i dożywotnia”, Piotrkowice, Strzeszkowice i część Olbrachcic, a zapewne również Błonie i Zakrzów. Dobra te najczęściej wydzierżawiała w późniejszym okresie krewnym swojego pierwszego męża. Rejestrowała bowiem $w$ grodzie krakowskim umowy zawierane $z$ Janem (pod zakładem 16000 florenów), Andrzejem Samuelem (w sprawie arendy Piotrkowic) oraz Erazmem (pod zakładem 14000 florenów) Dembińskimi ${ }^{25}$.

Małżonkowie Sienieńscy byli ludźmi dbającymi o dobra materialne. Systematycznie też powiększali swój majątek. Zbigniew odziedziczył po ojcu dużą wieś Chroślinę (25 łanów), a w $1612 \mathrm{r}$. kupił część wsi Boby (1,5 łanu). W 1624 r. przejął od Aleksandra Kołaczkowskiego zastaw na wsiach Radlna $z$ folwarkiem oraz Kłokowa (łącznie 3 łany) w powiecie pilzneńskim, województwie sandomierskim. Na mocy umowy zawartej $z$ dziedzicem tych wiosek, Andrzejem Chrząstowskim, który dał mu intromisję w te dobra, miał tu ulokowane 10000 florenów. Po pierwszej żonie otrzymał w dożywocie wsie Rokitnica i Bartkówka w województwie rawskim. Krystyna Uhrowiecka wniosła mu odzyskana od Zofii Strusiowej wieś Sielec z zamkiem w ziemi chełmskiej. Użytkowała też ona na mocy zapisu pierwszego męża wsie Piotrkowice (9,5 łanu), Zakrzów (3 łany) i Strzeszkowice (2,25 łanu) z częścią Olbrachcic w powiecie ksiąskim. Przed 1628 r. Zbigniew Sienieński kupił za 30000 florenów od swojego stryjecznego bratanka Jana Abrahama miasteczko

${ }^{25}$ Por. APL, LGR, nr 54, k. 571-573v (tu sporne dobra w ziemi mielnickiej przysądzono Mariannie Trzcińskiej, wnuczce Kaspra Dembińskiego i Maryny Kopciówny, żonie chorążego bełskiego Bartłomieja Bełżeckiego); ANK, Castriensia Cracoviensia Inscriptiones [dalej: CCI], nr 226, s. 2085; nr 231, s. 1269-1270, 1274-1276; nr 243, s. 1531-1532; nr 244, s. 865-874; AGAD, MK 185, k. 658v674 (3 III 1642 r. Stanisław Koniecpolski, kasztelan krakowski i hetman wielki koronny daje intromisję w dobra Horodyszcze w ziemi mielnickiej dzieciom Aleksandra Koniecpolskiego, które następnie ustępują z tych dóbr na rzecz starosty lubelskiego Zbigniewa Firleja i dokonuja podziału majątku po rodzicach); Z. Anusik, Sienieńscy..., s. 132-133. 
Prawno (1 łan) z wsiami Mazanów (2 łany) i Wola Lubaszowa (1,5 łanu) w powiecie urzędowskim. W 1629 r. dzierżawił też od dalszego krewnego Krystyny, Jana Uhrowieckiego, syna podkomorzyca chełmskiego Andrzeja wsie Uhrowsko (Uhrusk), Wola Uhrowiecka (Uhruska Wola), Zabuże i Mszanka w ziemi chełmskiej. Na przełomie 1628 i 1629 r. choraży lubelski Zbigniew Sienieński był więc właścicielem jednego miasta, trzech wsi całych i jednej części wsi (łącznie 31 łanów), a na dwóch kolejnych wsiach miał dożywocie po pierwszej żonie. Był także posesorem zastawnym dwóch wsi (3 łany) oraz dzierżawca czterech osad. Druga żona Sienieńskiego była w tym czasie właścicielka jednej wsi oraz dożywotnią użytkowniczką trzech innych (razem 14,75 łanu). W rękach małżonków Sienieńskich znajdowało się więc wówczas jedno miasteczko oraz 15 wsi całych i dwie części wsi. W dobrach leżących w powiatach urzędowskim, ksiąskim i pilzneńskim użytkowali oni 48,75 łanu chłopskiego ${ }^{26}$.

W 1629 r. Krystyna $z$ Uhrowieckich Sienieńska sprzedała swoja dziedziczną wieś Sielec z zamkiem Mikołajowi Daniłowiczowi najmłodszemu synowi nieżyjącego już podskarbiego wielkiego koronnego Mikołaja. Potrzebowała bowiem pieniędzy na sfinalizowanie innej dużej transakcji. W tym samym roku kupiła bowiem od Hieronima, Mikołaja i Zbigniewa Ossolińskich (w imieniu młodszych braci występował Hieronim), synów nieżyjącego Prokopa, wszystkie należące do nich dobra w powiecie urzędowskim. Zapłaciła za nie w sumie 80000 florenów, przy czym połowę należności uiściła od razu, a $z$ drugiej części została skwitowana dopiero w styczniu 1637 r. Niemniej jednak już w lipcu 1629 r. uzyskała intromisję do nabytych od Ossolińskich dóbr. Krystyna z Uhruska Sienieńska stała się tym samym właścicielka wsi Rybitwy $z$ folwarkiem (7 łanów), Nieszowa $z$ folwarkiem (3,5 łanu), Kolczyn $z$ folwarkiem (12,5 łanu), Bór seu Wola Borowa $z$ folwarkiem (13 łanów),

${ }^{26}$ Por. H. Gmiterek, op. cit., s. 194; ANK, CCI, nr 220, s. 976-989; Z. Anusik, Struktura własności ziemskiej $w$ powiecie pilzneńskim $w$ roku 1629, „Przegląd Nauk Historycznych" 2011, R. X, nr 2, s. 98 (tu jednak jako właściciel wsi Radlna i Kłokowa wymieniony został Mikołaj Kazimierski); idem, Sienieńscy..., s. 134-135; APL, LGR, nr 57, k. 576v-578v; nr 59, k. 694-695; Rejestr poborowy województwa krakowskiego z roku 1629, oprac. W. Domin, J. Kolasa, E. Trzyna, S. Żyga, red. S. Inglot, Wrocław 1956, s. 127; Rejestr poborowy województwa lubelskiego (powiat lubelski i urzędowski z r. 1626, powiat łukowski z r. 1620) [dalej: Rejestr lubelski 1626, oprac. J. Kolasa i K. Schuster, red. S. Inglot, Wrocław 1956, s. 92, 97-99; APL, ChGZ, nr 21, s. 1501. 
Kaliszany z folwarkiem (6,5 łanu), Ostrów seu Grodzisko (wieś zagrodnicza), Basonia (9 łanów), Łopoczno (5 łanów) i Wola Judaszowa (5 łanów). Majątek małżonków Sienieńskich powiększył się więc o dziewięć wsi i 61,5 łanu chłopskiego. W 1630 r. własnościa Zbigniewa i Krystyny było więc jedno miasto, 12 wsi całych i jedna część wsi w powiecie urzędowskim (razem 92,5 łanu). Ponadto Zbigniew Sienieński trzymał dożywotnio dwie wsie w województwie rawskim, a jego żona na tych samych zasadach cztery wsie całe i jedna część wsi w województwie krakowskim (razem 14,75 łanu). Nie była to oczywiście fortuna magnacka. Niemniej jednak, dysponujac majatkiem obejmujacym jedno miasto, 18 wsi całych i dwie części wsi, w których odnotowano ponad 107 łanów chłopskich, Sienieńscy $z$ pewnością należeli do grona zamożnej szlachty ${ }^{27}$.

Jak już wspomniano, 1 maja 1630 r. Zbigniew Sienieński otrzymał kasztelanię lubelska. W styczniu 1633 r. znalazł się w grupie kilku senatorów, którzy towarzyszyli zwłokom króla Zygmunta III i królowej Konstancji w drodze $z$ Warszawy do Krakowa. Wzią udział w uroczystościach pogrzebowych i w sejmie koronacyjnym Władysława IV. Przebywając w Krakowie, zawarł z żona jakaś umowę $z$ kasztelanem bieckim Andrzejem Samuelem, sędzią ziemskim krakowskim Stanisławem i Franciszkiem Dembińskimi pod bardzo wysokim zakładem 100000 florenów. Dnia 5 kwietnia 1633 r. skwitował Mikołaja Daniłowicza z 57000 florenów przyznanych mu wyrokiem Trybunału Koronnego. Zmarł przed 11 czerwca 1633 r. i pochowany został w kościele bernardynów w Lublinie. Pozostawił po sobie bardzo liczne potomstwo. Jak pamiętamy, jego pierwsza żona, Anna Leńkówna $z$ Rokitnicy urodziła mu dwóch synów i trzy córki: Pawła, Jana, Aleksandrę, Katarzynę i Krystynę. $\mathrm{Z}$ małżeństwa $\mathrm{z}$ Krystyną Uhrowiecka kasztelan lubelski pozostawił natomiast czterech synów i dwie córki: Mikołaja, Stanisława,

27 Por. APL, ChGZ, nr 21, s. 353-354 (tu w zapisce z 24 V 1628 r. Krystyna Sienieńska odnotowana jako właścicielka wsi Sielec z zamkiem), s. 1568-1569 (tu Sielec jako własność Mikołaja Daniłowicza); LGR, nr 58, k. 563-563v, 568v569, 571-571v, 596-596v (tu Stanisław Garwaski, kanonik krakowski i pleban w Piotrawinie, pozywa Krystynę Sienieńska o zaległe opłaty na rzecz Kościoła z wsi Kaliszany, których nie uiściła poprzednia właścicielka tych dóbr, Katarzyna z Biereckich Ossolińska); ANK, CCI, nr 231, s. 1270-1274 (tu Hieronim Ossoliński kwituje Krystynę Sienieńską z 40000 florenów, a ona zeznaje, że jest mu winna kolejnych 40000 florenów); nr 244, s. 874-875 (tu 15 I 1637 r. Hieronim Ossoliński kwituje Krystynę Sienieńska z 40000 florenów); Rejestr lubelski 1626, s. 100-101 (tu informacje o wsiach kupionych od Ossolińskich); Z. Anusik, Sienieńscy..., s. 135-136. 
Zbigniewa i Tomasza oraz Annę i Eufrozynę ${ }^{28}$. Warto w tym miejscu zaznaczyć również, że w chwili śmierci ojca wszystkie dzieci urodzone $z$ Leńkówny były już dorosłe. Najstarszy syn Zbigniewa $z$ drugiego małżeństwa - Mikołaj mógł się za to urodzić najwcześniej w drugiej połowie $1621 \mathrm{r}$. Miał więc wówczas około 12 lat. Aż do jej śmierci w 1639 r. dzieci Krystyny Uhrowieckiej pozostawały więc pod jej opieką. Matka występowała też w ich imieniu we wszystkich sprawach urzędowych ${ }^{29}$.

Warto zauważyć, że wdowa po Zbigniewie Sienieńskim pozostawała w dobrych stosunkach $z$ jego synami $z$ pierwszego małżeństwa. Już 27 lipca 1633 r. przeprowadzono podział dóbr po kasztelanie lubelskim. Paweł i Jan Sienieńscy otrzymali wówczas, za zgodą macochy, intromisję do Chrośliny i folwarku Prędków, a Krystyna $z$ Uhruska Sienieńska, za zgodą swoich pasierbów, w imieniu małoletnich synów objęła w posiadanie Prawno, Mazanów, Wolę Lubaszowa, Krasne (wieś nie występuje w Rejestrze poborowym z 1626 r.) i część w Bobach. Dwaj dorośli synowie kasztelana lubelskiego wraz $z$ wdowa po nim oraz jej małoletnimi synami byli też kilkakrotnie (w latach 1633-1635) pozywani przez Jakuba Sienieńskiego z Rakowa, który domagał się od nich zwrotu 20000 florenów i bezskutecznie usiłował wejść w posiadanie Chrośliny. O zwrot 8000 florenów pożyczonych przez Zbigniewa pozywali również wszystkich jego spadkobierców w 1636 r. Jadwiga z Gorzkowskich i Mikołaj Lubienieccy. Także i w tym przypadku Sienieńscy musieli odpierać zakusy wierzycieli na objęcie w realne posiadanie Chrośliny. Paweł i Jan Sienieńscy oraz kasztelanowa lubelska i wszystkie jej dzieci (obok czterech synów Krystyny wspomniano tu również jej dwie córki) wystapili też wspólnie w sporze o posiadaną niegdyś przez Zbigniewa kamienicę w Lublinie, którą ostatecznie przejął Marek Zwiartowski. W uzupełnieniu dodajmy, że już po śmierci drugiego męża, a więc po 1633 r. Krystyna Sienieńska borykała się jeszcze ze sprawami, które przejęła po zmarłym kilkanaście lat wcześniej bracie. Dopiero w połowie lat trzydziestych XVII w. Jan Meglewski skwitował bowiem zarówno ja sama, jak i jej synów $z$ drugiego małżeństwa ze zobowiązań, jakie zaciągnął wobec niego Marcin Uhrowiecki ${ }^{30}$.

${ }^{28}$ Por. AGAD, MK 178, k. 83v-85v; H. Gmiterek, op. cit., s. 194-195; ANK, CCI, nr 237, s. 1627-1628; nr 238, s. 241; Z. Anusik, Sienieńscy..., s. 136-137.

29 Por. Z. Anusik, Sienieńscy..., s. 136-137.

30 Por. APL, LGR, nr 62, k. 860v-861v, 1067-1067v, 1316v-1317v; nr 63, k. 1103-1103v, 1113-1114v (tu spór o kamienicę w Lublinie); nr 64, k. 527-527v 
Trzeba przyznać, że kasztelanowa lubelska była osoba zaradną i dobrze zarządzająca swoimi dobrami. Dbając o przyszłość swoich dzieci, systematycznie spłacała też długi po Zbigniewie Sienieńskim. Już w 1633 r. zastawiła ona wszystkie dobra po mężu, które przypadły w spadku jej synom za 45000 florenów swojemu stryjecznemu bratankowi, wspominanemu już kilkakrotnie Jakubowi Uhrowieckiemu. Ten ostatni nie od razu wszedł jednak w ich posiadanie, gdyż jeszcze w 1635 r. pozywał kasztelanową lubelską o nieprzekazanie mu zastawionych dwa lata wcześniej dóbr. W 1634 r. podróżująca po Lubelszczyźnie kasztelanowa przeżyła napad ze strony swawolnych żołnierzy. Do gospody nocującej w Popkowicach (wieś położona około $5 \mathrm{~km}$ na wschód od Urzędowa) Krystyny z Uhrowieckich Sienieńskiej wtargnęli porucznik Hans Krokier i choraży Piotr Świdrowski z kilkunastoma ludźmi z choragwi Jerzego von Ludinghausena Wolffa, dopuszczając się różnego rodzaju ekscesów. Zabili wówczas towarzyszącego Krystynie plebana rybickiego, księdza Stanisława Tulkiewicza i poranili dwóch szlachetnie urodzonych dworzan pani lubelskiej, Mikołaja Wolskiego oraz Walentego Czechowskiego. Napad na wdowę po senatorze wywołał natychmiastowa reakcję ze strony króla. Władysław IV, przebywający wówczas we Lwowie, 7 października 1634 r. powołał specjalna komisję do wyjaśnienia sprawy i osądzenia sprawców popełnionej zbrodni. Królewscy komisarze, starosta łukowski Bartłomiej Kazanowski i sekretarz JKM Daniel Iżycki wezwali zaś obwinionych do stawienia się w Popkowicach na posiedzenie doraźnego sądu. Nie znamy niestety zakończenia całej tej sprawy, gdyż nie pojawia się ona więcej w aktach lubelskich ${ }^{31}$.

W styczniu 1637 r. (a być może już w lipcu 1636 r.) Krystyna Sienieńska wydała za mąż swoja jedyną córkę $z$ pierwszego małżeństwa, Franciszkę Dembińska, która poślubiła szlachcica $z$ województwa kijowskiego, Ludwika Olizara Wołczkiewicza h. Choragwie Kmitów. Dała jej bardzo wysoki posag, wynoszacy 50000 florenów. Przy tej okazji roborowała w grodzie krakowskim kilka transakcji. Zastawiła wówczas Krzysztofowi Wiszowatemu za 50000 florenów wsie Nieszowa, Rybitwy, Kolczyn, Bór, Wola Judaszowa i Basonia.

(tu informacja, że dzierżawcą Chrośliny był wówczas Krzysztof Wiszowaty), 801-802; nr 65, k. 385v-386v; LZWZ, nr 111, k. 1055v-1556; Z. Anusik, Sienieńscy..., s. 137.

${ }^{31}$ Por. APL, LGR, nr 62, k. 1159v-1160; nr 63, k. 1180-1181v (tu sprawa napadu na Krystynę Sienieńską w Popkowicach); nr 64, k. 547; Z. A nusik, Sienieńscy..., s. 137. 
Oddała Hieronimowi Ossolińskiemu 40000 florenów, które była mu winna za nabyte w 1629 r. dobra. Scedowała na Ludwika Olizara zapis 20000 florenów dokonany na jej rzecz na wsiach Piotrkowice, Strzeszkowice, Błonie i Zakrzów przez podkomorzego mielnickiego Kaspra Dembińskiego. Zeznała wreszcie, że jest winna zięciowi 15000 florenów. W tym samym czasie Franciszka $z$ Dembian Olizarowa zeznała ustapienie $z$ dóbr ojczystych i macierzystych i skwitowała matkę $z$ wszelkich pretensji, a Ludwik Olizar Wołczkiewicz oprawił jej 50000 florenów posagu na swoich dobrach w województwie kijowskim. Dnia 2 czerwca 1639 r. złożona choroba, kasztelanowa lubelska spisała w Kaliszanach swój testament (cały tekst w aneksie). Jawi się w nim jako gorliwa katoliczka, wierna córa Kościoła rzymskiego, matka zatroskana o przyszłość swoich dzieci, regalistka, patriotka i pani dbajacca o swoje sługi i poddanych. W swojej ostatniej woli zawarła też wskazówki dotyczące swojego pogrzebu, kształcenia synów, wyposażenia córek i podziału pozostawionych przez siebie ruchomości. $Z$ treści testamentu wynika również, że kasztelanowa spłaciła wszystkie długi mężowskie oraz wykupiła zastawione wcześniej Jakubowi Uhrowieckiemu i Krzysztofowi Wiszowatemu dobra. Nie znamy niestety daty śmierci Krystyny z Uhrowieckich Sienieńskiej. Jej testament został bowiem oblatowany w grodzie lubelskim dopiero 6 czerwca 1645 r. Możemy jedynie przypuszczać, że zmarła ona zapewne wkrótce po spisaniu swojej ostatniej woli, a więc jeszcze w 1639 r. ${ }^{32}$

$$
* * *
$$

Edytowany dokument opracowano zgodnie $z$ zaleceniami instrukcji wydawniczej Kazimierza Lepszego ${ }^{33}, z$ pewnymi jednak, niewielkimi modyfikacjami. Zgodnie $z$ dominująca ostatnio tendencja w tego typu wydawnictwach nie dokonano pełnej modernizacji

${ }^{32}$ Por. ANK, CCI, nr 244, s. 738-742, 865-882; APL, LGR, nr 73, k. 522-523 (testament Krystyny z Uhrowieckich Sienieńskiej); Z. Anusik, Sienieńscy..., s. 137-138; A. B o ni ecki, op. cit., t. IV, s. 213 (tu informacja, że Franciszka Dembińska poślubiła Ludwika Olizara Wołczkiewicza już 27 VII 1636 r. w Lublinie). Warto też odnotować, że zdaniem Bonieckiego Olizar oprawił żonie 100000 florenów na swoich dobrach kijowskich. Por. ibidem. Ta ostatnia informacja wydaje się prawdziwa, gdyż zgodnie ze zwyczajem epoki, mężowie oprawiali posagi swoich żon w podwójnej ich wysokości.

${ }^{33}$ Instrukcja wydawnicza dla źródeł historycznych od XVI do połowy XIX wieku, red. K. Lepszy, Wrocław 1953. 
pisowni wyrazów staropolskich, zachowując ich cechy językowe. W związku z tym, bez zmian pozostawiono końcówki: -ej, -em, -emi, -ie, -ję. Nie zmieniano również litery „e" na „a”, jak wypadałoby to zrobić zgodnie z zasadami współczesnej ortografii. Samogłoski „y” oraz "i" oddano zgodnie $z$ obecnie obowiązujacymi regułami. Bez zmian pozostawiono słowa „wszytko”, „namniejszej”, „namilszej”, „szczyrej”, „nadgrody” itp. Uzupełniono pomijane czasami w tek-

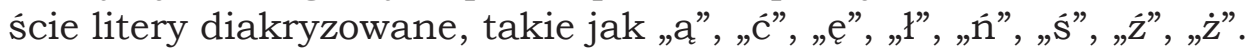
Do tekstu wprowadzono znaki interpunkcyjne. Dokonano modernizacji pisowni wszystkich imion, nazwisk i nazw miejscowych. Wielkich i małych liter użyto zgodnie ze współczesnymi zasadami. Rozwinięto wszystkie abrewiacje, rozwiązano skróty, uzupełniono pominięte przez pisarza litery. W nawiasach kwadratowych zaznaczono początek nowej strony w oryginale, jak również nieliczne pominięcia $\mathrm{w}$ tekście. W przypisach tekstowych zamieszczono uwagi odnoszace się do postaci zewnętrznej i brzmienia podstawy źródłowej. W przypisach rzeczowych dokonano identyfikacji występujących w tekście postaci i nazw miejscowych.

\section{Aneks}

Oryg.: Archiwum Państwowe w Lublinie, Grodzkie lubelskie, Relacje, nr 73, k. 522-525 (oblata 6 czerwca 1645 r.); dokument podał do akt Krzysztof Oszczepalski, sługa najstarszego syna testatorki, Mikołaja Sienieńskiego.

[k. 522]

W imię Trójce Przenajświętszej, Ojca, Syna i Ducha Świętego,

Ja, Krystyna $z$ Uroska Urowiecka, pozostała małżonka Zbigniewa $z$ Sienna Sienieńskiego, kasztelana lubelskiego, nauczywszy się w Kościele Katolickim Rzymskim słuchania słowa Bożego i przypatrzywszy się oczyma swojemi, że w cale i nieodmiennie statut ferowany i postanowiona przed wieki wola Boża pełniła się i pełni i wypełnia, że wszyscy, którzy się rodziemy, umieramy, a czasu i godziny kresu nie wiemy, tylko samę ostroge Zbawiciela naszego, który nam na przywitanie śmierci gotowymi zawsze być każe, żebyśmy nas dniem przed śmiercią tak się gotowali, jakoby po śmierci taki odpoczynek był w wiekuistej chwale duszom naszym. I taki tu na świecie zostawiła pokój, ukojenie, uśmierzenie, zgodę, 
miłość, jedność i nieroztargnienie ${ }^{34}$ między wami, dziatkami miłemi, pokrewnemi i powinnemi uprzejmemi, sługami i domownikami wiernymi i poddanemi życzliwemi, [wyraz nieczytelny] i pokoi czynieniem, między niesnaskami ciała i duszy, zmysłami i zamysłami i afektacjami naszymi, czego ja sobie życząc, i wespółek $z$ dziatkami mymi, pokrewnemi i powinnemi i ze wszytkiemi do mnie jakimkolwiek sposobem należącymi sługami, czeladką i domownikami $^{a} z$ łaski Pana i Stworzyciela mojego, rozumnie i rozmyślnie, ze szczyrej i dobrej woli długo uważnej i wolnej, nie wmówionej ani namówionej wolej, zdrowa na ciele i na zmysłach będąca, taki testament albo ostatnią wolę moja pod executią Panów i Dobrodziejów moich, Ich Mościów Panów Opiekunów zaufanych czynię i stanowię:

Syny i córki moje pierwszego i wtórego małżeństwa, Franciszkę Katarzynę z Dębian Olizarowa ${ }^{35}$, Mikołaja ${ }^{36}$, Stanisława ${ }^{37}$, Zbigniewa $^{38}$, Tomasza ${ }^{39}$, Annę ${ }^{40}$, Eufrozynę ${ }^{41}$ Sienieńskich pod błogosła-

a W tekście: „należącym sługom, czeladce i domownikom”.

${ }^{34} \mathrm{~W}$ tym przypadku chodziło testatorce o unikanie kłótni i sporów.

${ }^{35}$ Franciszka Katarzyna $z$ Dembińskich Olizarowa, jedyna córka testatorki z pierwszego małżeństwa, żona Ludwika Olizara Wołczkiewicza. Po jego śmierci wyszła ponownie za mąż za Stanisława Uchańskiego. Por. A. Boniecki, op. cit., t. IV, s. 213.

${ }^{36}$ Mikołaj Sienieński, najstarszy syn Krystyny Uhrowieckiej z drugiego małżeństwa. W 1645 r. poślubił wojewodziankę mazowiecką Krystynę Podoską. Po owdowieniu został księdzem. Zmarł przed 17 III 1660 r. Por. Z. Anusik, Sienieńscy..., s. 144-147.

37 Stanisław Sienieński, drugi syn testatorki z jej drugiego małżeństwa. Ożenił się z Magdaleną Wasilkowską. Skazany na infamię, został zabity w 1660 r. we wsi Bór przez ludzi starosty skalskiego Przecława Lanckorońskiego. Por. ibidem, s. $147-148$.

38 Zbigniew Sienieński, trzeci syn Krystyny Uhrowieckiej z jej drugiego małżeństwa. Poślubił Katarzynę Lanckorońska, bratanicę swojego szwagra, wojewody ruskiego i hetmana polnego koronnego Stanisława Lanckorońskiego. Pod koniec życia został miecznikiem chełmskim. Zmarł przed 4 II 1656 r. Por. ibidem, s. 149.

39 Tomasz Sienieński, czwarty, najmłodszy syn kasztelana lubelskiego Zbigniewa i Krystyny Uhrowieckiej. Zmarł młodo. Nie żył już w początkach czerwca 1652 r. Por. ibidem, s. 150.

40 Anna Sienieńska, starsza córka Krystyny Uhrowieckiej z jej drugiego małżeństwa. Zakonnica w klasztorze brygidek w Lublinie. Nowicjat odbyła w 1636 r., a śluby zakonne złożyła w roku 1638. Zmarła w 1684 r. Por. ibidem, s. 139.

${ }^{41}$ Eufrozyna Sienieńska, młodsza córka Zbigniewa Sienieńskiego i Krystyny Uhrowieckiej. W 1654 r. była żoną niewymienionego z imienia Humienieckiego. Nic więcej o niej nie wiadomo. Por. ibidem, s. 139. 
wieństwem Pana Boga w Trójcy Świętej jedynego i moim obowiązuje, aby we wszytkim i w namniejszej rzeczy wolej tej mojej ostatniej dosyć uczynili i w żadnej rzeczy nie przeczyli i na różne opaczne i wykrętne [k. 523] przez się albo przez inszych wykrętnych rozumienia nie obracali, jedno tak jako rzecz, istota i wola moja ostatnia prosta i szczera, umyślna, rozsądna i niżej opisana jest.

Naprzód tedy to, com wprzód od Stworzyciela mojego Nieba i ziemi wzięła $z$ wolej i łaski jego świętej, duszę moję Bogu wracam, które on jako prawdziwy Stworzyciel $z$ grzechów moich krwią swoja omyta, za zasługami, przyczyna i modlitwami Najświętszej i Błogosławionej Matki swojej Panny Mariej i wszytkich w niebie świętych Bożych będących zapomniawszy, podług od proroków podanej obietnice i od pokazanej w ciele ludzkim wszystkim grzesznikom łaski, grzechów moich niech przyjmie do łaski swej świętej i chwały wiecznej, jako własna robotę rak swoich Boskich wszechmocnych, w czym przy stałej wierze katolickiej rzymskiej mam zupełna i potężna nadzieję.

Ciało moje grzeszne chcę i pragnę i ta wola moja ostatnia nigdy nieodmienna, żeby w kościele lubelskim u ojców Bernardynów w kaplicy mojej własnejej świętej pamięci $z$ małżonkami memi [i] $z$ rodzonem moim ${ }^{43}$ pochowane było obyczajem i trybem Kościoła katolickiego rzymskiego bez wszelakiej pompy i odwłoki czasu, kosztu, katafalku w herbach, ale szaro, według zwyczaju tego zakonu i inszemi, jako najprzystojniejszymi obrzędami kościoła Bożego, na co aby dwanaście postawów szarego sukna tymże ojcom dano oprócz nadgrody za prace, które za żywota mego dla mnie podejmowali i przy pogrzebie podejmowane będą. O to też dziatek moich proszę, osobliwie Jego Mości Pana Olizara ${ }^{44}$ przez miłość, która jeżeli za żywota mieli ku mnie, Rodzicielce swojej, niech mi ja pokażą najwięcej po śmierci, żeby za directią Ich Mościów Panów Opiekunów i Executorów, Dobrodziejów moich nic się więcej nie starali jedno, żeby za duszę moją grzeszna jako najwięcej ofiar przenajświętszych przez ręce kapłanów, sług Bożych oddane były Bogu w Trójcy jedynemu i ubogich na pogrzeb ciała mojego

${ }^{42}$ Kaplica św. Antoniego Padewskiego ufundowana przez Uhrowieckich przy kościele Bernardynów w Lublinie.

${ }^{43}$ Mowa tu zarówno o dwóch mężach testatorki - Kasprze Dembińskim i Zbigniewie Sienieńskim, jak również o jej bracie, Marcinie Uhrowieckim.

${ }^{44}$ Ludwik Olizar Wołczkiewicz, mąż najstarszej córki Krystyny Uhrowieckiej. Właściciel dużych dóbr w województwie kijowskim. Zmarł już w 1640 r. 
z ukontentowaniem jałmużny świętej przyzwali, gdyż ci są, których jest Królestwo Niebieskie, którego przez jałmużny święte nabywamy $z$ nich. Tegoż też Jego Mości Pana Olizara dla miłości Bożej proszę, jako ukochanego syna mego, aby o dziatkach moich szczególnie wiedział, [k. 523v] radził, miłował, którym rozkazuję, aby Jego Mości we wszytkim jako mnie samej słuchali i szanowali. O kaplicę lubelska proszę. Synom moim kościół rybicki ${ }^{45}$ mnie za żywota ulubiony i wielce ukochany, w którym przez przyczynę Najświętszej Panny Mariej wszelkich łask od Pana Boga doznawała i dziatki moje, mianowicie syn mój Mikołaj, w równe zamiłowanie, zakochanie, obronę i opiekę polecam jego miłości teraźniejszego i na potym będącego pasterza jego, a osobliwie nabożeństwo bractwa różańca świętego przez staranie moje i fundacją do tego kościoła poprowadzone, żeby według fundacjej, nadania, intentiej, wolej, intercyzy prawem grodzkim lubelskim roborowana wniwczym nie przeciwili i to, comkolwiek naznaczyła, według liczby czasu nieodwłócznie oddawali pod błogosławieństwem Boga i moim. Którychem zrodziła o to tylko proszę i upominam, aby nabożeństwo, na które się pleban podjął, odprawowane było. Niech przestrzegaja, aby fundacja i intentia moja próżna nie była.

Napominam jako matka namilsze dziatki moje, aby wiary świętej katolickiej rzymskiej nie odstępowali nigdy, bo ta tylko jest wiara, która i początkiem pierwszem i następcami porządnie idącemi, dawnością wielka, jednościa zgodna, jest świadectwem nieomylnej prawdy, że ta tylko jest prawdziwa wiara Chrystusa Pana, a insze wymysły i uporczywość ludzka.

Królom i panom swoim niech zawsze będą wierni, miłej Ojczyźnie niech służą do gardeł swoich, pomnac na przodki swoje miłe.

Naukę, mądrość nad wszytkie majętności, zbiory i dostatki testamentem swoim synom leguję, upominając, aby pomnieli na familię i urodzenie swoje i najwięcej się w naukach zakochali. Bez mądrości i kapłanowi w kościele i senatorowi w senacie i żołnierzowi w obozie i szlachcicowi w kole braciej swojej i gospodarzowi w domu barzo pięknie i to jest skarb, który ani ogień pali, ani woda zabierze, ani nieprzyjaciel zagrabi, złodziej nie ukradnie.

45 Kościół parafialny we wsi Rybitwy, kupionej przez testatorkę od Ossolińskich. Wieś Rybitwy położona jest w odległości około $21 \mathrm{~km}$ na zachód od Urzędowa. W czasach staropolskich wieś leżała w powiecie urzędowskim województwa lubelskiego. 
[k. 524] To też oświadczam tem testamentem swoim: Ponieważ ta wola była nieboszczyka Dobrodzieja Mego Małżonka Pana Lubelskiego, że nie chce, aby dziatki moje młodsze i swoje przy inszych szkołach w naukach uczciwych zaprawiać się mieli jedno albo w Akademii Zamojskiej, albo Krakowskiej, a jeśliby za directia Ich Mościów Panów Opiekunów lat swoich dorośli i znaczny postępek w naukach tu w domu zacząwszy do cudzej ziemie jechali, upominam i przez miłość Boska proszę, aby tam swej wolej się wszelakiej warowali, towarzystwa się złego strzegli, kosztu i czasu darmo nie trawili, ale tylko nauk uczciwych pilnowali i w takie się dzieła zaprawowali, co by było ku chwale Bożej, ku ozdobie familiej, ku pomocy i ratunku Ojczyźnie i ku pociesze wszytkim powinnym, a nade wszytko bojaźń Bożą jako matka, najzacniejszy klejnot dziatkom moim zalecam, która gdy mieć będą, popłynie im $z$ nieba wszytko szczęście. Kapłanów, sług Bożych, przykładem świętej pamięci Ojca ich do poważania i poszanowania zalecam, upominając, aby ich jako sług Bożych w uczciwości mieli, bo ci są, którzy nas do nieba na rękach poniosa, osobliwie zakon bernardyński, tak moim przodkom, jako i wszytkiej familiej Ich Mościów Panów Sienieńskich $z$ dawna ulubiony, do szczególnej miłości i poszanowania, uczciwości i dobroczynności oddaję i zalecam pod błogosławieństwem moim.

Długi, którem na się przyjęła po nieboszczyku Małżonku moim i Dobrodzieju Panu Lubelskim, jeżeliby insze moje własne znalazły, płacić będa powinni synowie moi tak z ojczystych dóbr, jako i $z$ macierzystych i majętności mojej własnej i interesa od nich.

Córce mojej namilszej pierwszego małżeństwa Franciszce Olizarowej, ponieważ zrządzeniem Boskim i wolą Ich Mościów Panów Opiekunów w stan święty małżeński jest oddana przy błogosławieństwie macierzyńskim, oddaję miłość i zgodę zobopólną z dziatkami memi wtórego małżeństwa, aby jako teraz za żywota mego, tak i po śmierci mojej na duszę moja pamiętała o mnie, jakom ja ją za żywota miłowała miłością swa taką. Córka moja namilsza ${ }^{46}$, ponieważ na wieczną służbę Bożą jest oddana i Chrystusowi za oblubienicę poślubiona i ode mnie wyposażona, [k. 524v] której prowizją na majętności mojej własnej nieszowskiej ${ }^{47}$ zostawiłam

\footnotetext{
${ }_{46}$ Mowa tu o Annie Sienieńskiej, zakonnicy w klasztorze bernardynek w Lublinie.

${ }^{47}$ Nieszowa (dziś Nieszawa), wieś w parafii Rybitwy w powiecie urzędowskim województwa lubelskiego. Dobra te Krystyna Sienieńska kupiła od Ossolińskich.
} 
aż do jej śmierci, chcę i pod błogosławieństwem rozkazuję, aby synowie moi osobliwy wzgląd na nie mieli, szanowali i we wszytkim wygoda byli, a tę prowizją onej do śmierci powinna i w grodzie lubelskim zapisana bez żadnych trudności i kłopotów na czas naznaczony szczerze, $z$ miłościa, $z$ ochota, aby oddawali.

Eufrozynie, także córce mojej, jeżeliby do zakonu świętego zachęcona myśl miała, toż jej powinni dać bracia, a synowie moi z majętności, to jest cztery tysiące posagu do klasztoru, a dwa tysiące na prowizją. A jeżeliby inaczej Pan Bóg chciał, tedy wyposażyć onę będa powinni tak, jako sławnej pamięci Ociec ich, a Dobrodziej Mój córki swoje pierwszego małżeństwa ${ }^{48}$ wyprawił w stan święty małżeński.

Mikołajowi, synowi memu pierwszemu, z błogosławieństwem ojca mojego, pierścień diamentowy żżany ${ }^{49}$ odkazuję. Stanisławowi, synowi memu wtóremu jeśli duchownym zostanie, jeśli nie któremukolwiek $z$ synów moich za łaska Boska na to powołanemu, obranemu i poświęconemu pierścień szafirowy graniasty imieniem najsłodszy „Jezus” w tymże pierścieniu wydatnym nakazuję. Srebra i cokolwiek jest i będzie w ruchomych rzeczach jakiemikolwiek nazwiskami, imionami i rzeczami mianowanych chcę i pragnę i proszę Ich Mościów Panów Opiekunów, aby w równy dział między nie podzielono było, na Zbigniewa i Tomasza pomnac, którymem nic osobliwego nie zostawiła.

Sługom, służebnicom i niektórym domowym moim jeślibym przed śmiercią swoją zasłużonego nie zapłaciła, aby nieodwłócznie wszystkim zapłacono, nagrodzono, kontentowano, chcę i pragnę, żeby to wszytko tym oddano, co im osobno naznaczę i leguję podług regestru ręka moja podpisanego. Poddane moje dziatkom moim namilszym jako robaczki na nas robiące w łaskę i miłość ich poruczam, upominajac ich, aby nic nad zakazanie prawa Boskiego niedziel i świąt od Boga i kościoła postanowionych w robociznach nie wykraczali i żeby dzień jeden w tydzień wolny mieli podług dawnego zwyczaju, słuszności względu [k. 525] i folgi.

Na wsi ulokowała czynsz wyderkafowy od kwoty 1500 florenów. Por. APL, LGR, nr 85, k. 486v-488v.

48 Testatorka wspomina tu o dwóch córkach Zbigniewa Sienieńskiego i jego pierwszej żony, Anny Leńkówny. Aleksandra została żoną Stanisława Lanckorońskiego, wojewody ruskiego i hetmana polnego koronnego, a Katarzyna poślubiła Piotra Garwaskiego, starostę rzeczyckiego. Por. Z. An u sik, Sienieńscy..., s. 138.

${ }^{49}$ Chodzi tu o pierścień grawerowany. 
Tymże szpital rybicki zalecam, aby to wszytko com szczególnie odkazała, chętliwie oddali i przydali.

O to też Ich Mościów Panów Opiekunów proszę a dziatkom moim rozkazuje, aby dług Panien Zakonnych drzewickich ${ }^{50}$ trzech tysięcy monety i liczby polskiej, których ja na wyderkaf wzięła i na Kaliszanach ${ }^{51}$ zapis uczyniła, jako najprędzej albo summę oddali, albo jeżeliby się tak pannom pomienionym zdało, płat od nich brać, interessę od nich swego czasu bez żadnej trudności i odwłoki $\mathrm{z}$ ukontentowaniem jako ubogim sierotom oddawali. O co po wtóre proszę, a dziatek moich, aby inaczej nie czynili pod błogosławieństwem Boskim i moim upominam, gdyż przez ten czas sieroctwa mego, znoszac za łaska Boska wszytkie ciężary pozostałe po nieboszczyku Dobrodzieju Moim Panu Lubelskim jako działy i insze zapisy pokazuja, ten dług tylko na zniesienie dawnych długów na majętność moją własna wniosłam.

Ta jest ostatnia wola moja i testament, którym ja w Kaliszanach, w domu moim uczyniła i napisać kazała w Roku Pańskim tysiąc sześćset trzydziestym dziewiątym, dnia wtórego czerwca. Dla lepszej wiary ręka się swa podpisuje i pieczęć przykładam. Krystyna z Uruska Sienieńska, kasztelanka lubelska, ręką swa.

\section{Bibliografia}

\section{$\dot{Z}_{\text {Ródé ARCHIWALNE }}$}

Archiwum Główne Akt Dawnych w Warszawie [AGAD]

Metryka Koronna [MK] 100, 123, 133, 134, 154, 159, 178, 185.

Archiwum Narodowe w Krakowie [ANK]

Castriensia Cracoviensia Inscriptiones [CCI], nr 220, 226, 231, 237, 238, 243, 244.

Castriensia Cracoviensia Relationes, nr 653, 654.

${ }^{50}$ Mowa tu o klasztorze bernardynek w Drzewicy, miejscowości położonej w powiecie opoczyńskim województwa sandomierskiego. Miasto Drzewica leży w odległości około $20 \mathrm{~km}$ na północny wschód od Opoczna.

${ }^{51}$ Kaliszany, ośrodek dóbr nabytych przez testatorkę od Ossolińskich. Wieś Kaliszany położona była kilka km na północ od parafialnej wsi Rybitwy. Obie wsie usytuowane były w powiecie urzędowskim województwa lubelskiego. 
Archiwum Państwowe w Lublinie [APL]

Chełmskie grodzkie, Relacje, nr 1.

Chełmskie grodzkie, Zapisy [ChGZ], nr 5, 7, 8, 9, 13, 16, 17, 18, 19, 20, 21.

Lubelskie grodzkie, Relacje [LGR], nr 54, 57, 58, 59, 62, 63, 64, 65, 73, 85.

Lubelskie ziemskie, Wieczyste i zobowiązania [LZWZ], nr 109, 111.

Biblioteka Kórnicka PAN

sygn. BK 01467/1.

\section{$\dot{Z}_{\text {RÓDEA DRUKOWANE }}$}

Album Academiae Vitebergensis ab A. Ch. MDII usque ad A. MDLX, ed. C.E. Foerstmann, vol. I, Lipsiae 1841.

Archiwum Jana Zamoyskiego kanclerza i hetmana wielkiego koronnego, t. I (1553-1579), wyd. W. Sobieski, Warszawa 1904.

Archiwum Jana Zamoyskiego kanclerza i hetmana wielkiego koronnego, t. III (1582-1584), wyd. J. Siemieński, Warszawa 1913.

Archiwum Jana Zamoyskiego kanclerza i hetmana wielkiego koronnego, t. IV (1585-1588), wyd. K. Lepszy, Kraków 1948.

Duńczewski S., Herbarz wielu domow Korony Polskiey y W. X. Litewskiego, t. I, Kraków 1757.

Dyaryusz sejmu warszawskiego 1597 roku, [w:] Scriptores Rerum Polonicarum, t. XX, wyd. E. Barwiński, Kraków 1907, s. 1-124.

Niesiecki K., Herbarz polski, wyd. J.N. Bobrowicz, t. III, Lipsk 1839.

Niesiecki K., Herbarz polski, wyd. J.N. Bobrowicz, t. IX, Lipsk 1842.

Niesiecki K., Herbarz polski, wyd. J.N. Bobrowicz, t. X, Lipsk 1845.

Pamiętniki o Koniecpolskich. Przyczynek do dziejów polskich XVII wieku, wyd. S. Przyłęcki, Lwów 1842.

Paprocki B., Herby rycerstwa polskiego, wyd. K.J. Turowski, Kraków 1858.

Polacy w Bazylei. Z metryk Uniwersytetu Bazylejskiego, wyd. J. Kallenbach, Kraków 1888.

Regestra thelonei aquatici Wladislaviensis saeculi XVI, wyd. S. Kutrzeba, F. Duda, Kraków 1915.

Rejestr poborowy województwa krakowskiego z roku 1629, oprac. W. Domin, J. Kolasa, E. Trzyna, S. Żyga, red. S. Inglot, Wrocław 1956.

Rejestr poborowy województwa lubelskiego (powiat lubelski i urzędowski z r. 1626, powiat łukowski z r. 1620), oprac. J. Kolasa i K. Schuster, red. S. Inglot, Wrocław 1956.

Siemieński L., Pamiętniki o Samuelu Zborowskim, Poznań 1844. 


\section{Opracowania}

Anusik Z., Krag rodzinny Katarzyny z Sienna Myszkowskiej, podczaszyny lubelskiej (zm. 1619). Studium genealogiczno-obyczajowe, „Przegląd Nauk Historycznych” 2020, R. XIX, nr 2, s. 245-280.

Anusik Z., Krótkie życie i niespodziewana śmierć młodego magnata. Janusz Paweł ks. Ostrogski i jego testament z 6 sierpnia 1619 roku, „Przegląd Nauk Historycznych” 2020, R. XIX, nr 1, s. 215-239.

Anusik Z., Sienieńscy herbu Dębno (lubelska gałą́ rodu) w XVI i XVII wieku, „Przegląd Nauk Historycznych" 2021, R. XX, nr 1, s. 97-158.

Anusik Z., Struktura własności ziemskiej $w$ powiecie pilzneńskim $w$ roku 1629, „Przegląd Nauk Historycznych” 2011, R. X, nr 2, s. 69-108.

Bondyra W., Starostowie chełmscy w XVI wieku. Charakterystyka grupy, „Annales Universitatis Mariae Curie-Skłodowska, sectio F - Historia” 1991/1992, vol. XLVI/XLVII, s. 133-156.

Boniecki A., Herbarz polski, t. IV, Warszawa 1901.

Boniecki A., Herbarz polski, t. VI, Warszawa 1903.

Boniecki A., Herbarz polski, t. XI, Warszawa 1907.

Boniecki A., Herbarz polski, t. XIII, Warszawa 1909.

Bukowski J., Dzieje reformacyi w Polsce od wejścia jej do Polski aż do jej upadku, t. I, Kraków 1883.

Czaplewski P., Polacy na studiach w Ingolsztacie, Poznań1914.

Czarnecki W., Uhrowieccy herbu Suchekomnaty $w$ ziemi chełmskiej do połowy XVI wieku, „Wschodni Rocznik Humanistyczny” 2009, t. VI, s. 9-25.

Dubas-Urwanowicz E., Mężowie stanu, awanturnicy czy zdrajcy. Dzieje rodu Zborowskich w XVI wieku, Warszawa 2018.

Dworzaczek W., Hetman Jan Tarnowski. Z dziejów możnowładztwa małopolskiego, Warszawa 1985.

Gmiterek H., Sienicki Stanisław, [w:] Polski słownik biograficzny, t. XXXVII, Warszawa-Kraków 1996-1997, s. 162-163.

Gmiterek, Sienieński Zbigniew, [w:] Polski słownik biograficzny, t. XXXVII, Warszawa-Kraków 1996-1997, s. 193-195.

Górski K., Historya piechoty polskiej, Kraków 1893.

Instrukcja wydawnicza dla źródeł historycznych od XVI do połowy XIX wieku, red. K. Lepszy, Wrocław 1953.

Kawałko M.J., Rejowiec. Jego okolice i właściciele w latach 1531-1869, Lublin 2011.

Kowalska H., Snopkowski Stefan, [w:] Polski słownik biograficzny, t. XXXIX, Warszawa-Kraków 1999-2000, s. 407-408.

Libiszowska Z., Koniecpolski Aleksander, [w:] Polski słownik biograficzny, t. XIII, Wrocław-Warszawa-Kraków 1967-1968, s. 512-513.

Maciszewski J., Wojna domowa $w$ Polsce (1606-1609). Studium $z$ dziejów walki przeciwko kontrreformacji, cz. 1 (Od Stężycy do Janowca), Wrocław 1960. 
Marczewski J.K., Ad duos illustres appendix: córki szlacheckie Kasprowi Niesieckiemu i Adamowi Bonieckiemu nieznane, „Archiwa, Biblioteki i Muzea Kościelne" 2010, t. XCIII, s. 91-109.

Merczyng H., Zbory i senatorowie protestanccy $w$ dawnej Polsce, Warszawa 1904.

Plewczyński M., Potocki Andrzej, [w:] Polski słownik biograficzny, t. XXVII, Wrocław 1983, s. 768-769.

Posłowie ziemscy koronni 1493-1600, oprac. W. Uruszczak, I. Kaniewska, M. Ferenc, J. Byliński, red. I. Kaniewska, Warszawa 2013.

Siarczyński F., Obraz wieku panowania Zygmunta III, króla polskiego i szwedzkiego, cz. 1, Lwów 1828.

Sochaniewicz K., Ze studjów nad rozsiedleniem szlachty $w$ ziemi chełmskiej. Smokowie Ślepowrony w XV i XVI w. na Chetmszczyźnie, przybysze z Mazowsza, „Rocznik Towarzystwa Heraldycznego we Lwowie” 1924-1925, t. VII, s. $175-194$.

Tygielski W., Epistolografia staropolska jako źródło do badania mechanizmów politycznych, „Odrodzenie i Reformacja w Polsce” 1988, t. XXXIII, s. 63-79.

Tygielski W., W poszukiwaniu patrona, „Przegląd Historyczny” 1987, t. LXXVIII, z. 2, s. 191-210.

Urbaniak V., Zamoyszczycy bez Zamoyskiego. Studium dekompozycji ugrupowania politycznego, Warszawa 1995.

Urzędnicy województwa bełskiego i ziemi chełmskiej XIV-XVIII wieku. Spisy, oprac. H. Gmiterek i R. Szczygieł, red. A. Gąsiorowski, Kórnik 1992.

Urzędnicy województwa krakowskiego XVI-XVIII wieku. Spisy, oprac. S. Cynarski i A. Falniowska-Gradowska, red. A. Gąsiorowski, Kórnik 1990.

\section{NetOGRAFiA}

Hanula A., Kościót St Étienne du Mont w Paryżu i dwaj tajemniczy polscy studenci, https:// polskifr.fr/polska-we-francji/kosciol-st-etienne-du-mont-w-paryzui-dwaj-tajemniczy-polscy-studenci/ (dostęp: 16 VIII 2021).

NotKA O AUTORZE:

Prof. dr hab. Zbigniew Anusik - kierownik Katedry Historii Nowożytnej w Instytucie Historii Uniwersytetu Łódzkiego, członek Komitetu Nauk Historycznych Polskiej Akademii Nauk.

Zainteresowania naukowe: historia Polski i powszechna XVI-XVIII w., historia Szwecji XVI-XVIII w., stosunki polsko-szwedzkie w XVII-XVIII w., historia dyplomacji europejskiej w XVIII w., dzieje Wielkiej Rewolucji Francuskiej (1789-1799), elity dawnej Rzeczypospolitej, struktura własności ziemskiej w Rzeczypospolitej XVII w., genealogia polskich rodzin szlacheckich w XVI-XVIII w.

ఐ zbigniew.anusik@uni.lodz.pl 